\title{
The composition and flux of particulate and dissolved carbohydrates from the Rhone River into the Mediterranean Sea
}

\author{
C. Panagiotopoulos ${ }^{1}$, R. Sempéré ${ }^{1}$, J. Para ${ }^{1}$, P. Raimbault ${ }^{1}$, C. Rabouille ${ }^{2}$, and B. Charrière ${ }^{1}$ \\ ${ }^{1}$ Aix-Marseille Univ., Mediterranean Institute of Oceanography (MIO), UMR 7294, CNRS/INSU, UMR 235, IRD, 13288, \\ Marseille, Cedex 09; Université du Sud Toulon-Var (MIO), 83957, La Garde cedex, France \\ ${ }^{2}$ Laboratoire des Sciences du Climat et de l'Environnement (LSCE), Laboratoire Mixte CNRS-CEA, 1 Avenue de la Terrasse, \\ 91190 Gif sur Yvette, France
}

Correspondence to: C. Panagiotopoulos (christos.panagiotopoulos@univ-amu.fr)

Received: 27 September 2011 - Published in Biogeosciences Discuss.: 22 November 2011

Revised: 3 April 2012 - Accepted: 8 April 2012 - Published: 24 May 2012

\begin{abstract}
Carbohydrates are important components of the carbon cycle and may be used as indicators of the origin and the diagenetic status of marine and terrestrial organic matter. Nevertheless, comprehensive studies of both particulate (PCHO) and dissolved (DCHO) carbohydrates in rivers are scarce, and the seasonal and interannual variability of these compounds in relationship to the bulk particulate (POM) and dissolved organic matter (DOM) is largely unknown. For the period 2007-2009, we sampled once per month POM and DOM and measured the total suspended matter (TSM), POM, DOM, PCHO, and DCHO for the Rhône River, which flows into the Mediterranean Sea. Using these measurements, we estimated for the above parameters annual fluxes for the period 2007-2009. The estimated carbohydrate fluxes averaged $0.064 \pm 0.026 \times 10^{10}$ moles $^{-y_{r}}{ }^{-1}$ for PCHO and $0.042 \pm 0.008 \times 10^{10}$ moles $\mathrm{C} \mathrm{yr}^{-1} \mathrm{DCHO}$, representing $6 \%$ and $7 \%$ of the annual flux of POC and DOC, respectively. During flood and low-water periods, POM variations were reflected into the $\mathrm{PCHO}$ pool, whereas this was not observed for DOC and DCHO, indicating a decoupling between particulate and dissolved organic matter. Our results also showed that flood and low-water periods may be differentiated using the ratios PCHO/DCHO and POC/DOC, which had a significant relationship.

Based on the carbohydrate abundances in both the PCHO and DCHO pools, we conclude that this material mainly derives from allochthonous sources (vascular plants, bacteria and soils). Moreover, during flood events, an enrichment in mannose in POM was observed, probably reflecting an angiosperm source (leaves or grasses). By expanding our re-
\end{abstract}

sults to the northwestern Mediterranean Sea (Gulf of Lions), we found that the total organic carbon (TOC) fluxes of the Rhône River accounted for $\sim 1 \%$ of the standing stock of seawater TOC. Considering that glucose is the most abundant carbohydrate in both particulate and dissolved organic matter pools $(\sim 33 \%)$, its annual flux in the northwestern Mediterranean Sea was estimated to $3.8 \times 10^{8}$ moles glucose.

\section{Introduction}

Particulate and dissolved organic matter (POM and DOM) in river systems constitute a small pool of organic carbon $(\sim 0.02 \mathrm{GtC}$, assuming an average riverine freshwater volume of $2000 \mathrm{~km}^{3}$ and an average POM and DOM value of $5 \mathrm{mg} \mathrm{Cl}^{-1}$ ea.) nevertheless, it affects the global carbon budget not only because it serves as an important substrate for various organisms, including bacteria (Vannote et al., 1980; Sempéré et al., 2000; Bergfeld et al., 2009), but also because it constitutes a major source of reduced carbon to the world's oceans, with an annual flux of $\sim 0.4 \mathrm{GT} \mathrm{yr}^{-1}$ (Meybeck, 1982, 1983; Aufdenkampe et al., 2011). Moreover, riverine POM and DOM play a key role in several physical (e.g. erosion, sediment transport and accumulation, floods) and chemical processes (e.g. weathering of rocks, adsorption and desorption reactions, coagulation, UV transformations) occurring within the drainage basin and the river itself (Vigier et al., 2001; Mopper and Kieber, 2002 and references therein; Dagg et al., 2004; McKee et al., 2004; Mallin et al., 2006). 
Increasing attention is now being given to the dynamics and sources of POM and DOM in rivers because they significantly influence fisheries production and water quality (e.g. transport of pollutants, metal complexation) and also provide a record of natural and anthropogenic activities within the drainage basin (e.g. landscape sustainability, water clogging, river flow redistribution) (Kao and Liu, 1996, 1997; Solomon et al., 2000). Nevertheless, the chemical composition and processing of riverine organic substances is not well known because it is a complex function of diverse physical, chemi$\mathrm{cal}$, and biological processes; therefore, comprehensive analyses across dissolved and particulate forms are limited.

In general, characterizations of riverine POM and DOM concern analyses of bulk chemical properties (e.g. elemental composition and stable carbon isotope analyses) or measurements of broad compound classes (e.g. total carbohydrates or total amino acids). Analyses of individual compounds are scarce and typically involve components of only a family of compounds (e.g. lipids). However, previous investigations in rivers have suggested that POM and DOM are derived from decaying terrestrial plants (Opsahl and Benner, 1999) or in situ algal production (Kendall et al., 2001) and are thus rich in carbohydrates. Other minor compounds include nitrogenfree biomacromolecules such as terpenoids, humics, alkanes, phenols, tannins, and lignins (Degens et al., 1991; de Leeuw and Largeau, 1993; Kujawinski et al., 2002). Compared with carbohydrates, these nitrogen-free biomacromolecules are highly resistant to microbial degradation; however, photochemistry appears to control the decomposition of these biorefractory substances (Opsahl et al., 1999; Mopper and Kieber, 2002 and references therein).

Because rivers are dynamic ecosystems, it is also important to study the composition of POM and DOM throughout the seasons to estimate the watershed mass transport (i.e. flux) of the organic matter. Again, most of the previous studies in rivers have been confined to seasonal bulk measurements of the concentrations of POM and DOM, stable radiogenic isotopes (e.g. $\delta^{15} \mathrm{~N}, \delta^{13} \mathrm{C}, \Delta^{14} \mathrm{C}$; Alin et al., 2008), lignin biomarkers (Spencer et al., 2010) and very little is known about the temporal variability of other labile biochemicals (e.g. carbohydrates, amino acids; Hedges et al.,1994; Aufdenkampe et al., 2007).

Freshwater inputs from rivers play a major role in the Mediterranean Sea because they significantly enhance the primary productivity through the transport of carbon and nutrients (Moutin et al., 1998; Sempéré et al., 2000), and they contribute to the balance of water inputs through the Strait of Gibraltar (Copin-Montégut, 1993; Bray et al., 1995). Since the damming of the Nile, the Rhône River is the main contributor of freshwater to the Mediterranean Sea, accounting for approximately $50 \%$ of the total freshwater discharge into the sea (Margat, 1992; Bethoux and Gentili, 1999).

For the last decade, the Climate and Human-induced Alterations in Carbon Cycling at the River-seA connection (CHACCRA) group has been investigating the cycling and fluxes of bioactive elements, their potential impact on the climate, and the effects of hydrology changes on the Rhône River. However, these investigations focused on measurements of POM, DOM, nutrients, dissolved inorganic carbon (DIC), chromophoric dissolved organic matter (CDOM), total suspended matter (TSM) fluxes, and freshwater discharges (Coste and Raimbault, 1993; Sempéré et al., 2000; Pont et al., 2002; Para et al., 2010); therefore, little information regarding labile biochemicals (e.g. carbohydrates) in both particulate and dissolved fractions is currently available. In addition, previous data on the export of labile organic material and its relationship with the bacterial carbon demand, as previously assessed by Sempéré et al. (2000) for the Rhône River, cannot be validated if the relationships of organic chemical compositions to biological sources and the biodegradation mechanisms are not taken into account.

Here we report the first analyses of individual particulate and dissolved carbohydrates over a period of two years (2007-2009) along with DOM and POM measurements for the Rhône River. The organic material was collected during contrasting discharge conditions at a gauging station located approximately $50 \mathrm{~km}$ above the river mouth (see sampling site for details). Using these data, we estimated the carbohydrate fluxes from the Rhône River into the Mediterranean Sea over the same period and evaluated the major organic matter sources and degradation mechanisms occurring in the area. In this study, the objectives were the following:

a. To give an estimate of the annual fluxes of particulate and dissolved carbohydrates into the Mediterranean Sea;

b. to contrast the carbohydrate composition of POM and DOM collected during floods and low water discharge periods; and

c. to examine the distribution of the carbohydrates and determine whether carbohydrates can be used as tracers of organic matter sources and biological activities.

\section{Study area and sampling}

The Rhône River is $816 \mathrm{~km}$ long, drains an area of $100 \times 10^{3} \mathrm{~km}^{2}$, and has average annual discharge of $53 \times 10^{9} \mathrm{~m}^{3}$ of water and $10 \pm 5 \mathrm{Mt}$ of sediment (Ibanez et al., 1997; Sempéré et al., 2000; Pont et al., 2002; de Madron et al., 2003; Rabouille et al., 2008). The river stage fluctuates by 2 to $6 \mathrm{~m}$ annually, with a peak discharge in early spring and late autumn and a minimum in summer (Pont et al., 2002). The main tributaries of the Rhône River include the Saône River $\left(433 \mathrm{~m}^{3} \mathrm{~s}^{-1}\right)$ that has an oceanic pluvial regime (highest discharge in winter), the Isère River $\left(336 \mathrm{~m}^{3} \mathrm{~s}^{-1}\right)$, and the Durance River $\left(173 \mathrm{~m}^{3} \mathrm{~s}^{-1}\right)$. Inundation events are not observed due to the excessive canalization (with rare exceptions occurring near the delta in the Camargues area); 
therefore, extensive interaction of river water with the surrounding floodplain and its vegetation is small.

The Rhône Delta is divided into two outlets, the Petit Rhône and the Grand Rhône, corresponding to $20 \%$ and $80 \%$ of the water flow, respectively (Ibanez et al., 1997). The water samples analyzed in this study were collected between May 2007 and June 2009 at the town of Arles, which is located on the Grand Rhône (47.5 km upstream of the Mediterranean Sea). The Grand Rhône does not cross any productive marsh area (e.g. Camargues area) therefore the fluxes measured at Arles are nearly the same to those at the mouth of river. The collection site is among those routinely studied over the last two decades by the French scientific community (Moutin et al., 1998; Sempéré et al., 2000; Pont et al., 2002; Sicre et al., 2008; Ollivier et al., 2010). Water samples were collected at the SORA observatory station near the Compagnie Nationale du Rhône (CNR; http://www.cnr.tm.fr/fr/) gauging station in Arles at a distance of $7 \mathrm{~m}$ from the right bank and $0.5 \mathrm{~m}$ under the surface (Eyrolle et al., 2012). The sampling site has a rectangular cross section (width of the river $\sim 150 \mathrm{~m}$ ) and previous studies have shown that the vertical and horizontal distribution of suspended matter generally remains uniform (Pont et al., 2002).

\section{Methods}

Water samples were collected using automatic samplers installed in the observatory station. Each daily sample was the sum of 16 subsamples $(150 \mathrm{ml})$ collected every $90 \mathrm{~min}$ in polyethylene flasks containing $5 \mathrm{ml}$ of $\mathrm{HgCl}_{2}$ as a preservative, providing as such integrated daily samples. Each sample was then filtered (100 to $500 \mathrm{ml}$ according to the concentration of suspended particulate matter, TSM) through preweighted $\mathrm{GF} / \mathrm{C}$ glass fiber filters to collect suspended matter. The filters were dried and weighted to determine the total suspended matter concentration of (TSM in $\mathrm{mg}^{-1}$ ). Then, filters were analyzed for particulate organic carbon (POC) using the wet-oxidation procedure (see below). Organic carbon content (OC \%) of suspended matter was estimated by dividing the weight of organic carbon by the weight of TSM.

For particulate and dissolved carbon studies, river water (1-2 1) was collected once per month in glass bottles that were cleaned with $2 \%$ of $\mathrm{HCl}$. The bottles were closed with Teflon-lined screw caps and kept in the dark at $4{ }^{\circ} \mathrm{C}$ before filtration. The samples were brought to the lab in dry ice $(<24 \mathrm{~h})$ and filtered through $0.7 \mu \mathrm{m}$ retention-size filters $(\mathrm{GF} / \mathrm{F}-47 \mathrm{~mm} ; P<6.7 \mathrm{kPa})$ to separate the particulate and dissolved fraction. Prior to filtration, the $0.7 \mu \mathrm{m} \mathrm{GF} / \mathrm{F}$ filters were flushed with Milli-Q water and a small volume of the sample to minimize contamination (Yoro et al., 1999). Depending on the content of the organic matter in the samples, 200 to $500 \mathrm{ml}$ of water was filtered for subsequent particulate carbon and carbohydrate measurements. In general, for each water sample, two filters were obtained, unless more sample was available $(n=4)$. Immediately after filtration, the filters were rinsed with a few $\mathrm{ml}$ of Milli-Q water to eliminate salts and then freeze dried. After lyophilization, the filters were dried in a desiccator for $24 \mathrm{~h}$ and then stored in the dark at $-20^{\circ} \mathrm{C}$ until analysis. All glassware (i.e. bottles, vials, ampoules, and pipets) used in this study, including GF/F filters and quartz wool, were combusted at $450^{\circ} \mathrm{C}$ for $6 \mathrm{~h}$ prior to use.

The $0.7 \mu \mathrm{m}$-filtrates were re-filtered through $0.2 \mu \mathrm{m}$ retention-size filter (polycarbonate filter- $47 \mathrm{~mm}$ ) previously rinsed with $5 \% \mathrm{HCl}$, Milli-Q water, and $50 \mathrm{ml}$ of the sample. Triplicate sub-samples were collected for DOC analyses and transferred into $10 \mathrm{ml}$-glass ampoules (Wheaton ${ }^{\circledR}$ ), which were previously rinsed 3 times with sample. Then, $20 \mu \mathrm{l}$ of $\mathrm{H}_{3} \mathrm{PO}_{4}$ acid was added as a preservative, and the ampoules were flame-sealed. The ampoules were stored in the dark at $4^{\circ} \mathrm{C}$ until further analyses. The remaining sample was used for dissolved carbohydrate analyses and stored in polycarbonate bottles in the dark at $-20^{\circ} \mathrm{C}$. Similarly as above, for the the dissolved carbohydrates analyses, two sub-samples of the same water sample were analyzed, unless more sample was available $(n=4)$.

\subsection{Particulate and dissolved organic carbon (POC \& DOC) determination}

To remove inorganic carbon, the GF/F filters with collected particles were covered with $100 \mu \mathrm{l}$ of $0.5 \mathrm{~N} \mathrm{H}_{2} \mathrm{SO}_{4}$ and then dried at $60^{\circ} \mathrm{C}$. The POC analyses on the filters were carried out using high temperature combustion $\left(900^{\circ} \mathrm{C}\right)$ performed on a CN Integra mass spectrometer (Raimbault et al., 2008). Analytical errors based on duplicate analysis were approximately $5 \%$.

DOC concentration was measured by high temperature combustion on a Shimadzu TOC 5000 analyzer, as described in Sohrin and Sempéré (2005). A four-point calibration curve was constructed daily with standards prepared by diluting a stock solution of potassium hydrogen phthalate in Milli-Q water. To avoid random errors associated with day-to-day instrument variability, all of the samples from a given experiment were analyzed in a single day. The procedural blanks (runs with Milli-Q water) ranged from 1 to $2 \mu \mathrm{M} \mathrm{C}$ and were subtracted from the values presented here. Deep seawater reference samples (provided by D. Hansell; Univ. Miami) were run daily $(43.5 \mu \mathrm{M} \mathrm{C}, \mathrm{CV}=2-3 \%, n=4)$ to check the accuracy of the DOC analysis. Total organic carbon (TOC) concentrations were estimated by summing POC and DOC. 


\subsection{Particulate and dissolved carbohydrates (PCHO \& DCHO) determination}

\subsubsection{Carbohydrate extraction and isolation}

Filters for the $\mathrm{PCHO}$ analysis were cut out with clean scissors and transferred to 40-ml glass tubes with Teflon-lined screw caps. A few $\mathrm{ml}$ of $12 \mathrm{M} \mathrm{H}_{2} \mathrm{SO}_{4}$ were added using a pipette, and the samples were allowed to sit for $2 \mathrm{~h}$ at room temperature, after which the acid was diluted to $1.2 \mathrm{M}$ with Milli$\mathrm{Q}$ water. Then, the samples were sparged with $\mathrm{N}_{2}$ and hydrolyzed in a sand bath for $3 \mathrm{~h}$ at $100^{\circ} \mathrm{C}$ (Cowie and Hedges, 1984; Panagiotopoulos and Wurl, 2009). The hydrolysis was stopped by placing the tubes in an ice bath for 5-10 min.

Aliquots of $7 \mathrm{ml}$ were neutralized with $\mathrm{CaCO}_{3}$ (precombusted at $450^{\circ} \mathrm{C}$ for $6 \mathrm{~h}$ ) in $10 \mathrm{ml}$ glass tubes. Prior to neutralization, adonitol, at a final concentration of $1 \mu \mathrm{M}$, was added to the sample as an internal standard to estimate the losses during the neutralization steps. After neutralization, the samples were centrifuged 3-4 times at $4000 \mathrm{rpm}$ for $5 \mathrm{~min}$, and the supernatant was filtered through quartz wool and pipetted into scintillation vials. The vials were frozen at $4{ }^{\circ} \mathrm{C}$ until time of analysis (this never exceeded $24 \mathrm{~h}$ ).

For the DCHO analysis, two aliquots each $9 \mathrm{ml}$ of the $0.2 \mu \mathrm{m}$-filtered sample were freeze dried, and the obtained powder was treated using the above procedure (i.e. hydrolysis, and neutralization). Because of the low salinity $(<1 \%$ o of the sampling site, our water samples did not require any further treatment (e.g. desalination steps).

\subsubsection{Liquid chromatography}

A Dionex ICS-3000 anion exchange chromatograph fitted with a pulsed amperometric detector (HPAEC-PAD) was used for all carbohydrate analyses. The separation of the carbohydrates was performed on a Dionex CarboPac PA-1 analytical column and a Dionex CarboPac PA-1 guard column. An amino trap was placed before the guard column to retain amino acids and similar compounds, which may interfere with the carbohydrate analysis. The analytical column, the guard column, and the amino trap were placed into a thermal compartment. The temperature of the compartment was set at $17^{\circ} \mathrm{C}$, which was found to be optimal for the separation of the monosaccharides in previous studies (Panagiotopoulos et al., 2001; Panagiotopoulos and Sempéré, 2005a). Sugars were detected by an electrochemical detector (ED40-Dionex) set in the pulsed amperometric mode (standard quadruplepotential). Data acquisition and processing were performed using the Dionex software Chromeleon.

\section{Analytical conditions}

Eleven individual monosaccharides were detected in the hydrolysates of the particulate and dissolved organic material, including deoxysugars (fucose, and rhamnose), pentoses (arabinose, ribose, and xylose), one amino sugar (glu- cosamine), hexoses (galactose, glucose, and mannose), and acidic sugars (galacturonic, and glucuronic acids).

Neutral and amino sugars were separated with an isocratic $19 \mathrm{mM} \mathrm{NaOH}$ elution at $17^{\circ} \mathrm{C}$ (eluent A: $20 \mathrm{mM}$ $\mathrm{NaOH}$; eluent B: Milli-Q water) following Panagiotopoulos et al. (2001). Acidic sugars (i.e. uronic acids) were detected in a separate analysis using a gradient of two mobile phases (eluent $\mathrm{C}$ : $1 \mathrm{M} \mathrm{NaOH}$; eluent D; $0.5 \mathrm{M} \mathrm{CH}_{3} \mathrm{COONa}$ ). The gradient program used for this chromatographic separation was as follows:

1. 0-12 min $62.5 \%$ eluent B, $7.5 \%$ eluent C, $30 \%$ eluent $\mathrm{D}$,

2. $12-13$ min $80 \%$ eluent B, $20 \%$ eluent C (ramp 5),

3. $13-20 \min 80 \%$ eluent B, $20 \%$ eluent C (end of the analysis).

The flow rate was set at $0.7 \mathrm{ml} \mathrm{min}^{-1}$ for both neutral and acidic sugars analyses.

\section{Precision, detection limit, blanks, and recoveries}

The precisions, as shown by the coefficient of variation $(\mathrm{CV})$, were $5-10 \%$ and $0.9-2.0 \%(n=6)$ for the peak area and retention time, respectively, for repeated injections of a standard solution of $50 \mathrm{nM}$ per sugar. Repeated injections $(n=6)$ of a typical particulate sample resulted in a CV of $4-6 \%$ and $0.03-0.21 \%$ for the peak area and retention time, respectively, for all sugars. The detection limit of the method $(S / N=3)$ was approximately $10 \mathrm{nM}$ for neutral and amino sugars, whereas for acidic sugars it was $20 \mathrm{nM}$.

The procedural blank consisted of Milli-Q hydrolyzed in the same manner as the samples (see above). Sugars were not detected in the blank. Adonitol was recovered at a percentage of 80-95\%; however, we have chosen not to correct our original data.

\subsection{Statistics}

Principal components analysis (PCA) was used to reduce the multidimensional nature of the data set and to evaluate the interrelationships among the carbohydrates (variables). PCA has been successfully used in previous studies to assess the origin or the degradation status of organic matter (Panagiotopoulos and Sempéré, 2005b; He et al., 2010) and was performed using the individual carbohydrate concentrations (i.e. glucose, and mannose) as well as the POC and DOC data (Table 1). The PCA statistics were performed using the statistical package XLSTAT 2010.2 (Microsoft Excel add-in program). 
Table 1. Water discharge $(Q)$, total suspended matter (TSM), weight percentage of organic carbon, particulate and dissolved organic carbon (POC, DOC), DOC/POC ratios, particulate and dissolved carbohydrates (PCHO, DCHO), and DCHO/ PCHO ratios measured in the Rhône River during the period May 2007 to June 2009.

\begin{tabular}{|c|c|c|c|c|c|c|c|c|c|}
\hline Date & $\begin{array}{r}Q \\
\left(\mathrm{~m}^{3} \mathrm{~s}^{-1}\right)\end{array}$ & $\begin{array}{r}\mathrm{TSM} \\
\left(\mathrm{mg} \mathrm{l}^{-1}\right)\end{array}$ & $\begin{array}{l}\mathrm{OC} \\
(\%)\end{array}$ & $\begin{array}{l}\text { POC } \\
(\mu \mathrm{M})\end{array}$ & $\begin{array}{l}\text { DOC } \\
(\mu \mathrm{M})\end{array}$ & $\begin{array}{r}\mathrm{DOC} / \\
\mathrm{POC}\end{array}$ & $\begin{array}{r}\text { PCHO } \\
(\mu \mathrm{M})\end{array}$ & $\begin{array}{r}\text { DCHO } \\
(\mu \mathrm{M})\end{array}$ & $\begin{array}{r}\mathrm{DCHO} / \\
\mathrm{PCHO}\end{array}$ \\
\hline 21 May 2007 & 1570 & 22.7 & 3.7 & 60.5 & 144 & 2.4 & 0.68 & 3.1 & 4.5 \\
\hline 26 Jun 2007 & 1910 & 115 & 3.7 & 141 & 117 & 0.83 & 1.7 & - & - \\
\hline 27 Jul 2007 & 1300 & 17.3 & 3.1 & 45.2 & 123 & 2.7 & 0.32 & 1.2 & 3.9 \\
\hline 11 Dec 2007 & 2660 & 91.3 & 2.5 & 135 & 168 & 1.2 & 2.1 & 1.7 & 0.81 \\
\hline 17 Jan 2008 & 2823 & 47.5 & 2.9 & 120 & 199 & 1.7 & 1.6 & 1.6 & 1.0 \\
\hline 5 Feb 2008 & 1835 & 22.6 & 4.6 & 201 & 135 & 0.67 & 1.1 & - & - \\
\hline 11 Mar 2008 & 1233 & 6.1 & 5.2 & 16.0 & 120 & 7.5 & 0.42 & 1.2 & 2.9 \\
\hline 25 Mar 2008 & 1853 & 20.8 & 3.5 & 77.0 & 124 & 1.6 & 1.3 & 1.5 & 1.2 \\
\hline 8 Apr 2008 & 1458 & 8.0 & 4.9 & 31.4 & 127 & 4.0 & 0.54 & 1.8 & 3.3 \\
\hline 22 Apr 2008 (flood) & 3244 & 88.1 & 2.4 & 288 & 169 & 0.59 & 2.4 & 1.9 & 0.79 \\
\hline 13 May 2008 & 1156 & 6.2 & 6.4 & 20.6 & 122 & 5.9 & 0.22 & 1.6 & 7.1 \\
\hline 27 May 2008 & 2669 & 124 & 2.4 & 124 & 95.7 & 0.77 & 1.1 & 1.1 & 1.0 \\
\hline 30 May 2008 (flood) & 3822 & 920 & 2.3 & 2334 & 120 & 0.05 & 14.2 & 1.4 & 0.10 \\
\hline 18 Jun 2008 & 2399 & 72.6 & 3.2 & 286 & 117 & 0.41 & 1.6 & 1.0 & 0.64 \\
\hline $1 \mathrm{Jul} 2008$ & 1366 & 14.9 & 4.4 & 53.7 & 80.0 & 1.5 & 0.44 & 1.2 & 2.7 \\
\hline 8 Sep 2008 (flood) & 2983 & 285 & 2.8 & 1311 & 216 & 0.16 & 11.0 & 2.5 & 0.23 \\
\hline 22 Oct 2008 (flood) & 3817 & 388 & 3.0 & 412 & 128 & 0.31 & 4.0 & 1.3 & 0.32 \\
\hline 18 Nov 2008 & 1342 & 13.3 & 4.8 & 76.1 & 141 & 1.8 & 0.88 & 1.5 & 1.7 \\
\hline 3 Dec 2008 & 1445 & 17.2 & 3.6 & 53.9 & 137 & 2.5 & 1.3 & 2.2 & 1.7 \\
\hline 7 Feb 2009 (flood) & 4800 & 1044 & 1.8 & 408 & 164 & 0.40 & 5.1 & 1.0 & 0.20 \\
\hline 3 Mar 2009 & 1950 & 23.4 & 3.0 & 111 & 122 & 1.1 & 1.9 & 1.2 & 0.62 \\
\hline 10 Mar 2009 & 1400 & 10.4 & 2.6 & 25.4 & 120 & 4.7 & 0.82 & - & - \\
\hline 7 Apr 2009 & 1600 & 27.1 & 3.0 & 52.7 & 116 & 2.2 & 0.93 & 1.4 & 1.4 \\
\hline 22 Apr 2009 & 1600 & 134 & 2.8 & 40.4 & 107 & 2.6 & 0.69 & 1.2 & 1.7 \\
\hline 9 Jun 2009 & 1450 & 14.2 & 3.2 & 35.5 & - & - & 0.92 & - & - \\
\hline Average & 2147 & 141 & 3.4 & 258 & 134 & 1.9 & 2.3 & 1.5 & 1.8 \\
\hline $\mathrm{SD}$ & 971 & 270 & 1.1 & 506 & 30.6 & 1.9 & 3.3 & 0.53 & 1.7 \\
\hline
\end{tabular}

\section{Results}

\subsection{Bulk parameters}

\subsubsection{Water discharge $(Q)$, total suspended matter (TSM), organic carbon content of particles (OC \%), POC, and DOC concentrations}

The Rhône River exhibits two periods of peak discharge: a spring peak related to snowmelt in the Alpine and Massif Central watersheds and a fall peak related to storm events originating from humid air masses over the Mediterranean Sea. During the sampling period (May 2007-June 2009), discharge fluctuated from 1233 to $4800 \mathrm{~m}^{3} \mathrm{~s}^{-1}$, whereas TSM concentrations varied between 6 and $1044 \mathrm{mg} \mathrm{l}^{-1}$, with peak values occurring during the flood of February 2009 (Table 1). Less intense flood episodes occurred in April, May, September and October 2008. The flood event observed in late May 2008 was due to artificial releases of water from the Serre-Ponçon dam (located approximately $250 \mathrm{~km}$ north-east of the sampling station), while the 8 September 2008 event was related to an exceptional watershed overflow occurred $200 \mathrm{~km}$ in the north. Therefore, these measurements were excluded for annual fluxes estimations (see below). During the flood events of 2008, discharge varied from 2983 to $3822 \mathrm{~m}^{3} \mathrm{~s}^{-1}$, corresponding to TSM concentrations of 88 $1044 \mathrm{mgl}^{-1}$ (Table 1).

The organic carbon content (OC\% wt) of the particles ranged from 1.8 to $6.4 \%$ (Table 1 ) and was similar to that reported in previous studies in the Rhône (Cauwet et al., 1990; Sempéré et al., 2000) and other riverine systems (Ittekkot, 1988; Hedges et al., 1994). The POC concentrations ranged from 16 to $2334 \mu \mathrm{M} \mathrm{C}$, with the highest values recorded during the flood events (Table 1; Fig. 1a). In agreement with previous investigations, the OC \% correlated well with TSM, according to the formula OC $\%=-0.012 \log \mathrm{TSM}+0.054$ $(r=0.71, n=24, p<0.0001)$, and likely results from the combination of autochthonous organic particles with landderived material and resuspended particles (Meybeck et al., 1982; Thurman, 1985; Ittekkot, 1988; Sempéré et al., 2000).

Finally, DOC concentrations averaged $134 \pm 30.6 \mu \mathrm{M} \mathrm{C}$, which was lower but in the same order of magnitude as 


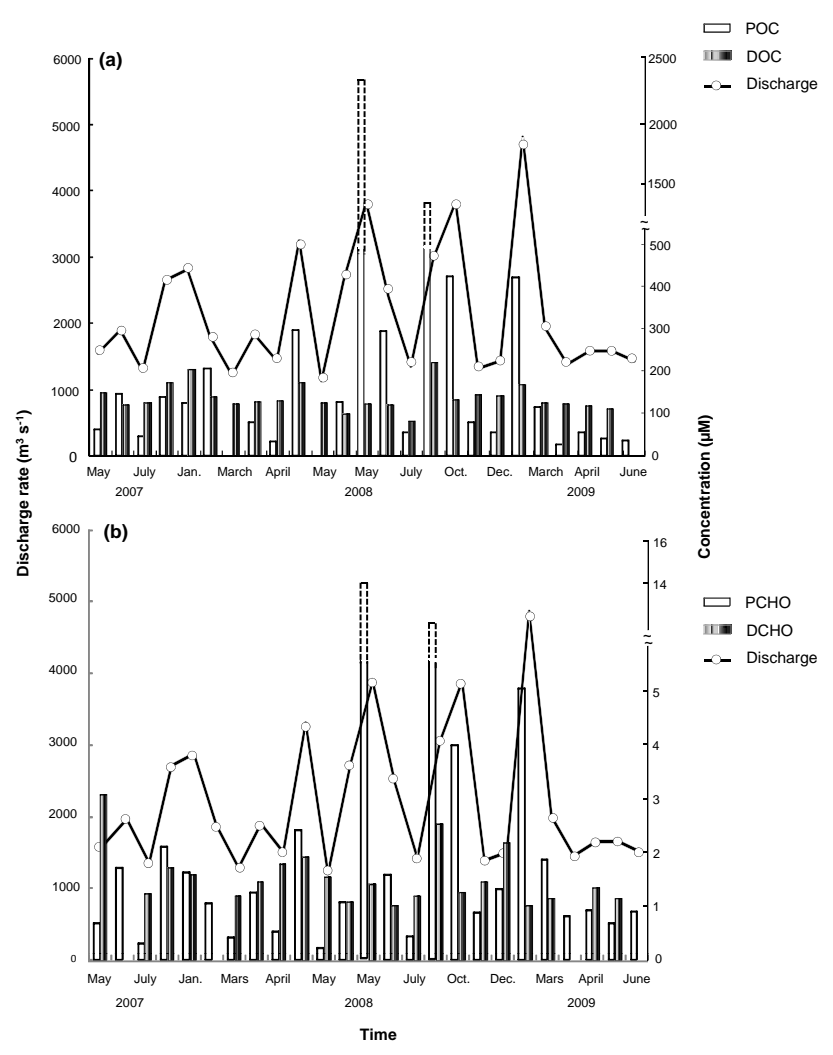

Fig. 1. Daily discharge of the Rhône River (in $\mathrm{m}^{3} \mathrm{~s}^{-1}$ ) between May 2007 and June 2009 as a function of (a) POC and DOC concentrations (in $\mu \mathrm{M} \mathrm{C}$ ) and (b) PCHO and DCHO concentrations (in $\mu \mathrm{M})$.

seen in previous studies in the Rhône (Cauwet et al., 1990; Sempéré et al., 2000). The DOC/POC ratios reached minimum values (0.1-0.6) during flood episodes, which indicates a higher POC transport compared with DOC during these events (Table 1).

\subsubsection{Particulate and dissolved carbohydrate concen- trations (PCHO \& DCHO) and their contribution to the organic carbon pool}

PCHO concentrations ranged from 0.22 to $11 \mu \mathrm{M}$ and, similar to POC, were higher during the flood episodes (2.4$11 \mu \mathrm{M}$; Table 1). The particulate sugars represented 3 to $18 \%$ of POC (PCHO-C/POC \%); however, the maximum observed values did not coincide with the flood episodes (Table 2). Our results are within the expected range of values measured in other riverine systems in Europe (Danube and Tech rivers; da Cunha et al., 2002; Reschke et al., 2002), America (Amazon, Parana, and São Francisco rivers; Depetris and Kempe, 1993; Hedges et al., 1994; Jennerjahn and Ittekkot, 1999), Africa (Niger and Orange rivers; Thurman, 1985), and Asia (Ganges and Indus rivers; Ittekkot et al., 1982; Thurman, 1985).
The DCHO concentrations averaged $1.5 \pm 0.53 \mu \mathrm{M}$ and accounted for 4 to $13 \%$ of DOC (Tables 1 and 3). Our results are similar to previous values reported from the Parana (4$25 \%$, Depetris and Kempe, 1993), Williamson (2\%, Sweet and Perdue, 1982), Niger (0.3-21\%, Thurman, 1985) and Mackenzie (2.7-21\%, Thurman, 1985) rivers, and in ultrafiltrated organic matter collected from Arctic rivers (2-4\%, Amon and Benner, 2003) or the Amazon (3-5\% Hedges et al., 1994). Similar to the DOC/POC ratios, DCHO/PCHO reached minimum values $(0.1-0.8)$ during flood episodes, which indicated higher particulate carbohydrate transport than dissolved carbohydrates during these events (Table 1).

\subsubsection{Relations between water discharge and POC, DOC, PCHO and DCHO}

Daily POC, DOC, PCHO and DCHO loadings were calculated by multiplying their concentrations by the daily water discharge $(Q)$ during the sampling period. The discharge rate correlated significantly with POC and PCHO fluxes as shown by the correlation coefficients:

$(\mathrm{POC})=0.1154(Q)-112.99(n=23, r=0.90)$
$(\mathrm{PCHO})=0.0012(Q)-1.0077(n=23, r=0.94)$

In our study, $Q$ did not correlate with DOC and DCHO. As the relationship was found not to be significant, DOC and DCHO transport (see below) was estimated by multiplying the average concentration (Tables 1 and 3 ) by the corresponding river discharge. The DOC and DCHO error is given by the standard deviation found for the average DOC and DCHO concentrations. The same approach has already been used by Sempéré et al. (2000) to estimate annual dissolved inorganic carbon (DIC) fluxes.

\subsubsection{Annual fluxes of TSM, POC, DOC, PCHO and DCHO}

TSM measurements were available for each day between 2007 and 2009 and therefore annual TSM fluxes were calculated by multiplying TSM with the corresponding flow rate. Annual fluxes of carbohydrates along with POC and DOC were estimated using the above equations for each day from 2007-2009 (Table 4).

From May 2007 to June 2009, the average total discharge was estimated to be $47 \pm 9.6 \mathrm{~km}^{3} \mathrm{yr}^{-1}$, whereas $4.31 \pm 3.55 \times 10^{6} \mathrm{t} \mathrm{yr}^{-1}$ of suspended solids reached the Mediterranean Sea. These values are similar to those reported by Sempéré et al. (2000) (period 19871996; $\left.54 \pm 12 \mathrm{~km}^{3} \mathrm{yr}^{-1} ; \quad 9.90 \pm 6.53 \times 10^{6} \mathrm{tyr}^{-1}\right)$ or Pont et al. (2002) (period 1967-1996; $53.6 \mathrm{~km}^{3} \mathrm{yr}^{-1}$; $\left.7.4 \times 10^{6} \mathrm{tyr}^{-1}\right)$, which were estimated after extrapolation from similar relationships. The calculated average POC and DOC fluxes were $1.03 \pm 0.42$ and $0.63 \pm 0.13 \times 10^{10}$ moles $\mathrm{C} \mathrm{yr}^{-1}, \quad$ respectively (Table 4). These values are approximately lower than 
Table 2. Relative abundance of particulate carbohydrates (PCHO in mol \%) and their contribution to the POC pool during the sampling period.

\begin{tabular}{|c|c|c|c|c|c|c|c|c|c|c|c|c|}
\hline Date & Fuc & Rha & Ara & GlcN & Gal & Glc & Man & Xyl & Rib & GalUA & $\begin{array}{r}\text { PCHO } \\
(\mu \mathrm{M}-\mathrm{C})\end{array}$ & $\begin{array}{l}\mathrm{PCHO}-\mathrm{C} / \\
\mathrm{POC}(\%)\end{array}$ \\
\hline 21 May 2007 & 7.1 & 6.3 & 9.8 & 5.1 & 16.5 & 34.3 & 7.9 & 11.3 & 1.0 & 0.5 & 3.9 & 6.5 \\
\hline 26 Jun 2007 & 5.5 & 3.7 & 7.4 & 7.2 & 23.5 & 32.7 & 6.5 & 11.3 & 1.6 & 0.7 & 9.8 & 7.0 \\
\hline 27 Jul 2007 & 6.4 & 5.5 & 7.0 & 4.4 & 17.1 & 41.2 & 3.6 & 11.2 & 2.3 & 1.4 & 1.8 & 4.1 \\
\hline 11 Dec 2007 & 6.8 & 8.8 & 10.1 & 3.7 & 16.2 & 28.5 & 8.9 & 13.2 & 2.7 & 1.2 & 12.1 & 9.0 \\
\hline 17 Jan 2008 & 7.8 & 9.0 & 11.5 & 3.2 & 16.4 & 26.6 & 7.7 & 14.9 & 2.4 & 0.6 & 9.2 & 7.6 \\
\hline 5 Feb 2008 & 6.1 & 7.7 & 11.4 & 4.8 & 14.3 & 29.5 & 9.7 & 13.2 & 2.8 & 0.5 & 6.0 & 3.0 \\
\hline 11 Mar 2008 & 9.4 & 6.3 & 15.5 & 3.9 & 14.7 & 28.1 & 4.7 & 14.5 & 2.6 & 0.3 & 2.4 & 14.8 \\
\hline 25 Mar 2008 & 7.1 & 5.5 & 9.7 & 4.4 & 16.7 & 34.0 & 6.0 & 14.3 & 2.0 & 0.2 & 7.1 & 9.3 \\
\hline 8 Apr 2008 & 6.0 & 6.4 & 7.9 & 4.9 & 13.2 & 42.4 & 5.6 & 13.2 & 0.0 & 3.1 & 3.1 & 9.9 \\
\hline 22 Apr 2008 (flood) & 5.8 & 5.5 & 8.6 & 3.4 & 17.8 & 35.2 & 7.9 & 13.9 & 1.6 & 0.4 & 13.8 & 4.8 \\
\hline 13 May 2008 & 5.9 & 5.7 & 5.3 & 6.9 & 13.3 & 42.6 & 9.3 & 8.0 & 2.2 & 0.8 & 1.3 & 6.2 \\
\hline 27 May 2008 & 7.4 & 5.8 & 10.4 & 3.0 & 19.8 & 26.1 & 7.0 & 14.9 & 5.6 & & 6.1 & 4.9 \\
\hline 30 May 2008 (flood) & 4.2 & 6.1 & 9.2 & 3.0 & 17.1 & 32.1 & 10.6 & 16.5 & 1.1 & 0.2 & 80.5 & 3.4 \\
\hline 18 Jun 2008 & 5.0 & 7.8 & 11.7 & 2.9 & 17.3 & 30.9 & 8.1 & 13.9 & 1.8 & 0.5 & 9.1 & 3.2 \\
\hline $1 \mathrm{Jul} 2008$ & 4.8 & 11.0 & 7.0 & 3.9 & 7.9 & 43.6 & 7.1 & 10.1 & 3.1 & 1.6 & 2.5 & 4.7 \\
\hline 8 Sep 2008 (flood) & 4.6 & 8.4 & 10.8 & 4.5 & 18.2 & 28.8 & 12.4 & 9.8 & 2.1 & 0.6 & 63.2 & 4.8 \\
\hline 22 Oct 2008 (flood) & 6.1 & 8.2 & 11.0 & 3.5 & 15.7 & 32.0 & 9.9 & 11.8 & 1.4 & 0.5 & 22.9 & 5.6 \\
\hline 18 Nov 2008 & 3.9 & 9.8 & 7.6 & 3.3 & 7.2 & 45.3 & 8.7 & 9.9 & 1.8 & 2.5 & 5.1 & 6.7 \\
\hline 3 Dec 2008 & 3.5 & 8.0 & 33.3 & 1.7 & 8.3 & 25.6 & 6.0 & 10.5 & 1.8 & 1.5 & 7.3 & 13.6 \\
\hline 7 Feb 2009 (flood) & 5.2 & 7.8 & 15.0 & 4.5 & 16.7 & 25.7 & 12.8 & 9.8 & 1.7 & 1.5 & 28.8 & 7.1 \\
\hline 3 Mar 2009 & 5.7 & 9.1 & 11.3 & 2.7 & 17.1 & 27.0 & 9.0 & 15.0 & 2.5 & 0.6 & 10.7 & 9.6 \\
\hline 10 Mar 2009 & 6.6 & 9.0 & 20.1 & 2.1 & 14.5 & 23.4 & 7.2 & 13.8 & 1.9 & 1.4 & 4.6 & 18.0 \\
\hline 7 Apr 2009 & 6.7 & 9.1 & 10.8 & 4.0 & 18.6 & 29.8 & 8.9 & 9.5 & 1.8 & 0.9 & 5.4 & 10.2 \\
\hline 22 Apr 2009 & 6.0 & 8.5 & 6.0 & 4.2 & 13.9 & 42.4 & 6.8 & 9.5 & 1.9 & 0.9 & 4.0 & 10.0 \\
\hline 9 Jun 2009 & 4.8 & 5.4 & 21.2 & 3.9 & 17.0 & 29.4 & 6.9 & 9.5 & 1.3 & 0.6 & 5.2 & 14.6 \\
\hline Average & 5.9 & 7.4 & 11.6 & 4.0 & 15.6 & 32.7 & 8.0 & 12.1 & 2.0 & 0.8 & 13.0 & 7.9 \\
\hline SD & 1.3 & 1.8 & 6.0 & 1.2 & 3.6 & 6.6 & 2.2 & 2.3 & 1.0 & 0.6 & 19.0 & 4.0 \\
\hline
\end{tabular}

A blank indicates that this compound was below detection.

Abbreviations: Fuc., Fucose; Rha., Rhamnose; Ara., Arabinose; GlcN., Glucosamine; Gal., Galactose; Glc., Glucose; Man., Mannose; Xyl., Xylose; Rib., Ribose; GalUA., Galacturonic acid.

those estimated by Sempéré et al. (2000) (period 19871996; $\mathrm{POC}=1.62 \pm 0.92 \times 10^{10}$ moles $\mathrm{yr}^{-1} ; \quad \mathrm{DOC}=$ $1.08 \pm 0.30 \times 10^{10}$ moles $\left.\mathrm{yr}^{-1}\right)$, but similar to those reported by Cauwet et al. (1990) (period 1986; DOC = $0.8-1.1 \times 10^{10}$ moles $\mathrm{yr}^{-1}$ ).

Finally, the PCHO-C fluxes $\left(0.064 \pm 0.026 \times 10^{10}\right.$ moles $\left.\mathrm{yr}^{-1}\right) \quad$ were higher than those of their dissolved counterparts, DCHO-C $\left(0.042 \pm 0.008 \times 10^{10}\right.$ moles $\left.\mathrm{C} \mathrm{yr}^{-1}\right)$, indicating that carbohydrates are mainly exported to the Mediterranean Sea in the particulate form.

\subsection{Molecular composition of carbohydrates}

\subsubsection{Distribution of carbohydrates in POM and DOM}

Aldohexoses were the most abundant compound class (0.3$6 \mu \mathrm{M})$ of carbohydrates in POM and accounted for approximately half of the PCHO $(54 \pm 6 \%)$. Aldopentoses were second in abundance $(29 \pm 7 \%)$, followed by deoxysug- ars $(13 \pm 2 \%)$, amino sugars $(4 \pm 1 \%)$ and uronic acids $(1 \pm 1 \%)$. Glucose was by far the most abundant sugar, averaging $33 \pm 7 \%$ of the PCHO, followed by galactose $(16 \pm 4 \%)$, xylose $(12 \pm 2 \%)$, and arabinose $(12 \pm 6 \%)$ (Table 2). Mannose was next in abundance $(8 \pm 2 \%)$ followed by fucose and rhamnose with equivalent contributions (6$7 \%$ ) to the PCHO pool. Finally, glucosamine, ribose, and galacturonic acid were the least abundant carbohydrates accounting for $<5 \%$ of the PCHO (Table 2). Ribose is a fragile monosaccharide and generally is destroyed during acid hydrolysis. Therefore, the results presented here should be looked as minimum ribose concentrations.

Similar to POM, aldohexoses were the most abundant compound class in DOM, accounting for approximately half of the DCHO $(53 \pm 7 \%)$. Aldopentoses contributed $21 \pm 5 \%$ to the DCHO pool, followed by deoxysugars $(14 \pm 4 \%)$, uronic acids $(6 \pm 3 \%)$, and amino sugars $(6 \pm 2 \%)$. Glucose was again the most abundant sugar, averaging $33 \pm 7 \%$ of the DCHO, followed by mannose $(11 \pm 3 \%)$, galactose $(11 \pm 4 \%)$, and arabinose $(9 \pm 4 \%)$ 
Table 3. Relative abundance of dissolved carbohydrates (DCHO in mol \%) and their contribution to the DOC pool during the sampling period.

\begin{tabular}{|c|c|c|c|c|c|c|c|c|c|c|c|c|}
\hline Date & Fuc & Rha & Ara & $\mathrm{GlcN}$ & Gal & Glc & Man & Xyl & Rib & GalUA & $\begin{array}{l}\text { DCHO } \\
(\mu \mathrm{M}-\mathrm{C})\end{array}$ & $\begin{array}{c}\mathrm{DCHO}-\mathrm{C} / \\
\mathrm{DOC}(\%)\end{array}$ \\
\hline 21 May 2007 & 3.6 & 3.6 & 6.6 & 3.1 & 18.6 & 52.3 & 5.1 & 3.8 & & 3.3 & 18.2 & 12.6 \\
\hline 26 Jun 2007 & N/A & N/A & N/A & N/A & N/A & N/A & N/A & N/A & N/A & N/A & N/A & N/A \\
\hline 27 Jul 2007 & 5.5 & 6.0 & 23.4 & 7.3 & 9.5 & 27.6 & 9.2 & 5.1 & & 6.2 & 7.1 & 5.7 \\
\hline 11 Dec 2007 & 5.6 & 5.8 & 5.1 & 4.8 & 12.5 & 30.9 & 15.8 & 11.7 & & 7.8 & 10.0 & 5.9 \\
\hline 17 Jan 2008 & 5.8 & 5.4 & 7.8 & 4.1 & 5.2 & 47.3 & 8.4 & 3.5 & & 12.5 & 9.3 & 4.7 \\
\hline 5 Feb 2008 & N/A & N/A & N/A & N/A & N/A & N/A & N/A & N/A & N/A & N/A & N/A & N/A \\
\hline 11 Mar 2008 & 9.4 & 8.6 & 8.5 & 7.7 & 11.0 & 25.2 & 14.7 & 6.7 & & 8.1 & 7.1 & 5.9 \\
\hline 25 Mar 2008 & 9.9 & 10.6 & 9.3 & 4.9 & 10.9 & 26.7 & 11.2 & 10.4 & & 6.1 & 8.5 & 6.9 \\
\hline 8 Apr 2008 & 5.4 & 4.9 & 12.3 & 4.8 & 19.0 & 32.1 & 8.4 & 7.3 & & 5.8 & 10.0 & 7.9 \\
\hline 22 Apr 2008 (flood) & 8.4 & 9.3 & 9.6 & 4.5 & 9.3 & 34.7 & 10.2 & 8.8 & & 5.2 & 11.1 & 6.6 \\
\hline 13 May 2008 & 6.4 & 8.1 & 11.1 & 5.5 & 7.3 & 28.8 & 14.6 & 10.0 & 3.2 & 4.9 & 8.9 & 7.3 \\
\hline 27 May 2008 & 9.6 & 12.3 & 6.6 & 8.2 & 13.5 & 27.6 & 12.2 & 10.0 & & 0.0 & 6.3 & 6.6 \\
\hline 30 May 2008 (flood) & 8.1 & 9.2 & 8.1 & 6.6 & 9.0 & 36.1 & 10.0 & 6.0 & & 7.0 & 8.3 & 6.9 \\
\hline 18 Jun 2008 & 7.0 & 5.9 & 8.9 & 7.5 & 4.9 & 37.6 & 12.1 & 5.3 & & 10.9 & 6.0 & 5.1 \\
\hline 1 Jul 2008 & 6.0 & 7.6 & 5.1 & 7.5 & 9.3 & 32.8 & 11.9 & 5.8 & 7.0 & 7.0 & 6.9 & 8.7 \\
\hline 8 Sep 2008 (flood) & 7.4 & 8.8 & 9.9 & 4.2 & 7.7 & 36.1 & 9.4 & 7.6 & 5.2 & 3.6 & 14.6 & 6.7 \\
\hline 22 Oct 2008 (flood) & 9.8 & 11.6 & 6.6 & 6.7 & 9.9 & 24.0 & 11.6 & 10.5 & 3.7 & 5.6 & 7.3 & 5.7 \\
\hline 18 Nov 2008 & 8.1 & 7.5 & 13.9 & 5.9 & 13.5 & 29.2 & 9.0 & 8.1 & & 4.7 & 8.4 & 6.0 \\
\hline 3 Dec 2008 & 5.1 & 4.7 & 11.4 & 3.1 & 7.3 & 46.2 & 10.7 & 7.9 & & 3.5 & 12.7 & 9.3 \\
\hline 7 Feb 2009 (flood) & 6.5 & 6.7 & 6.4 & 9.8 & 5.6 & 39.6 & 9.9 & 5.6 & & 9.7 & 6.0 & 3.7 \\
\hline 3 Mar 2009 & 6.0 & 6.8 & 5.6 & 6.4 & 14.2 & 28.8 & 15.2 & 10.0 & & 7.0 & 6.8 & 5.5 \\
\hline 10 Mar 2009 & N/A & N/A & N/A & N/A & N/A & N/A & N/A & N/A & N/A & N/A & N/A & N/A \\
\hline 7 Apr 2009 & 7.6 & 7.4 & 11.2 & 7.2 & 12.2 & 27.7 & 13.4 & 7.1 & & 6.2 & 7.8 & 6.7 \\
\hline 22 Apr 2009 & 7.3 & 7.1 & 8.6 & 7.5 & 11.5 & 29.1 & 14.6 & 7.9 & & 6.5 & 6.7 & 6.3 \\
\hline 9 Jun 2009 & N/A & N/A & N/A & N/A & N/A & N/A & N/A & N/A & N/A & N/A & N/A & N/A \\
\hline Average & 7.1 & 7.5 & 9.3 & 6.1 & 10.6 & 33.4 & 11.3 & 7.6 & 0.9 & 6.3 & 8.9 & 6.7 \\
\hline $\mathrm{SD}$ & 1.7 & 2.3 & 4.0 & 1.8 & 3.8 & 7.7 & 2.7 & 2.3 & 2.0 & 2.7 & 3.1 & 1.8 \\
\hline
\end{tabular}

N/A: No available data.

A blank indicates that this compound was below detection.

(Table 3). Xylose, rhamnose and fucose accounted for $\sim 7$ $7.5 \%$ of the DCHO. Ribose was generally below the detection limit, whereas galacturonic acid was higher in abundance $(6 \pm 3 \%)$ in the DCHO pool than the PCHO (Tables 2 and 3).

\section{Discussion}

\subsection{Fluxes and lability of organic matter in the Rhône River}

Previous investigations assessed POM lability after the classification of TSM into nine groups of a specific range (0-15, 15-50, 50-150 $\mathrm{mg}^{-1}$, etc.) (Ittekkot, 1988). This classification was based on the carbohydrate and amino acid measurements in POM, which are generally considered to be labile compounds (susceptible to bacterial degradation), and because of their quantitative significance in POM (Moran and Hodson, 1989; Wakeham et al., 1997; Panagiotopoulos and Sempéré, 2005b and references therein; He et al., 2010). We used the same classifications and estimated the labile POC (LPOC) fluxes into the Gulf of Lions over the period 20072009 from the calculated TSM concentrations.

Our results showed that LPOC was mainly distributed between TSM concentrations of $0-15 \mathrm{mg} \mathrm{l}^{-1}$ $\left(52 \%\right.$ of the data) and $15-50 \mathrm{mgl}^{-1}$ (29\% of the data). Over the 3-yr estimation, the LPOC fluxes ranged from 0.23 to $0.36 \times 10^{10}$ moles $\mathrm{C} \mathrm{yr}^{-1}$ (average $0.28 \times 10^{10}$ moles $\mathrm{yr}^{-1}$ ) and were approximately four fold lower than those of the POC fluxes, but four fold higher than those of the PCHO-C fluxes (Table 4). The LPOC fluxes accounted for $23-32 \%$ (av. $27 \%$ ) of the bulk POC. The latter average value is approximately four fold higher than the average value of the PCHO-C fluxes/POC fluxes ( $\sim 6 \%$; Table 4$)$ over the sampling period. This difference may be attributed to the presence of other labile compounds (e.g. amino acids, nucleic acids) in POM, which are included in the LPOC estimates. 
Table 4. Annual Rhône River Discharges, and fluxes of Total Suspended Matter (TSM), Particulate Organic Carbon (POC), Dissolved Organic Carbon, Particulate (PCHO-C), and Dissolved (DCHO-C) carbohydrates estimated for the sampling period (2007-2009).

\begin{tabular}{|c|c|c|c|c|c|c|}
\hline Year & $\begin{array}{l}\text { Discharges } \\
\mathrm{Km}^{2} \mathrm{yr}^{-1}\end{array}$ & $\begin{array}{l}\text { TSM fluxes } \\
10^{6} \mathrm{t} \mathrm{yr}^{-1}\end{array}$ & $\begin{array}{r}\text { POC Fluxes } \\
10^{10} \text { moles } \mathrm{yr}^{-1}\end{array}$ & $\begin{array}{r}\text { DOC Fluxes } \\
10^{10}{\text { moles } \mathrm{C} \mathrm{yr}^{-1}}^{-1}\end{array}$ & $\begin{array}{l}\text { PCHO-C Fluxes* } \\
10^{10} \text { moles }^{*} \mathrm{yr}^{-1}\end{array}$ & $\begin{array}{l}\text { DCHO-C Fluxes } \\
10^{10} \text { moles }^{*} \mathrm{yr}^{-1}\end{array}$ \\
\hline 2007 & 43.3 & 3.14 & $0.83 \pm 0.25$ & $0.58 \pm 0.13$ & $0.052 \pm 0.011$ & $0.039 \pm 0.013$ \\
\hline 2008 & 58.3 & 8.29 & $1.52 \pm 0.46$ & $0.78 \pm 0.18$ & $0.095 \pm 0.021$ & $0.052 \pm 0.018$ \\
\hline 2009 & 40.4 & 1.49 & $0.76 \pm 0.23$ & $0.54 \pm 0.12$ & $0.048 \pm 0.010$ & $0.037 \pm 0.012$ \\
\hline 3 yr average & 47 & 4.31 & 1.03 & 0.63 & 0.064 & 0.042 \\
\hline Standard deviation & 9.6 & 3.55 & 0.42 & 0.13 & 0.026 & 0.008 \\
\hline
\end{tabular}

POC, and PCHO-C fluxes were calculated from the linear relationships between the daily discharge and the corresponding loads based on 23 points between May 2007 and June 2009.

DOC and DCHO-C fluxes were calculated by multiplying mean DOC and DCHO-C concentration by the water discharge (see Tables $2 \& 3$ ) between May 2007 and June 2009.

* Carbon content of carbohydrates considering that $1 \mathrm{~mol}$ of carbohydrate contains 6 moles of carbon.

During the sampling period, we found two significant relationships between PCHO-C and POC, and PCHO-C and LPOC (Fig. 2a, b). This result is in agreement with previous studies highlighting the role of carbohydrates as active labile components of the riverine POM pool (Ittekkot and Arain, 1986; Ittekkot, 1988; Depetris and Kempe, 1993; Hedges et al., 1994; Bergamaschi et al., 1999). Although our data cover only a two year period, this is the first time these relationships have been established in a riverine system; thus, it might be useful to evaluate the carbohydrate content of POC or the amount of LPOC in riverine particles and vice versa. Further measurements of amino acids or other labile compounds in POM in rivers may also help to improve or establish similar relationships.

The refractory particulate organic carbon (RPOC) fluxes were calculated after the subtraction of the LPOC fluxes from the bulk POC fluxes. Our results showed that the RPOC

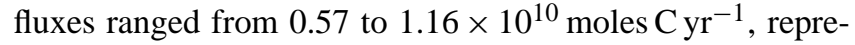
senting 68 to $77 \%$ of the bulk POC. The RPOC contribution to the bulk POC falls into the range of 55-95\% reported for several world rivers (Ittekkot, 1988) and matches well with the RPOC found in the Orinoco $(\sim 80 \%)$, Zaire $(\sim 80 \%)$, Indus $(\sim 80 \%)$, and Brahmaputra $(\sim 80 \%)$ rivers. RPOC survives microbial degradation and is mostly lost in estuaries, although a small fraction is incorporated into coastal marine sediments (Prahl et al., 1994; Hedges et al., 1997; Keil et al., 1997).

Similar to POM, riverine DOM is composed of old and young material (i.e. labile DOC; LDOC); nevertheless, the young component of DOM predominates, as shown by radiocarbon measurements (Raymond and Bauer, 2001). Biodegradable riverine DOM originates mainly from autochthonous in situ production, whereas refractory DOM results from POM solubilization and/or the weathering of sedimentary rocks and soils (Smith and Hollibaugh, 1993; Kao and Liu, 1996; Keil et al., 1997; Schillawski and Petsch, 2008).

In contrast to LPOC, which can be estimated by the TSM particle range (see above), literature data for LDOC in rivers

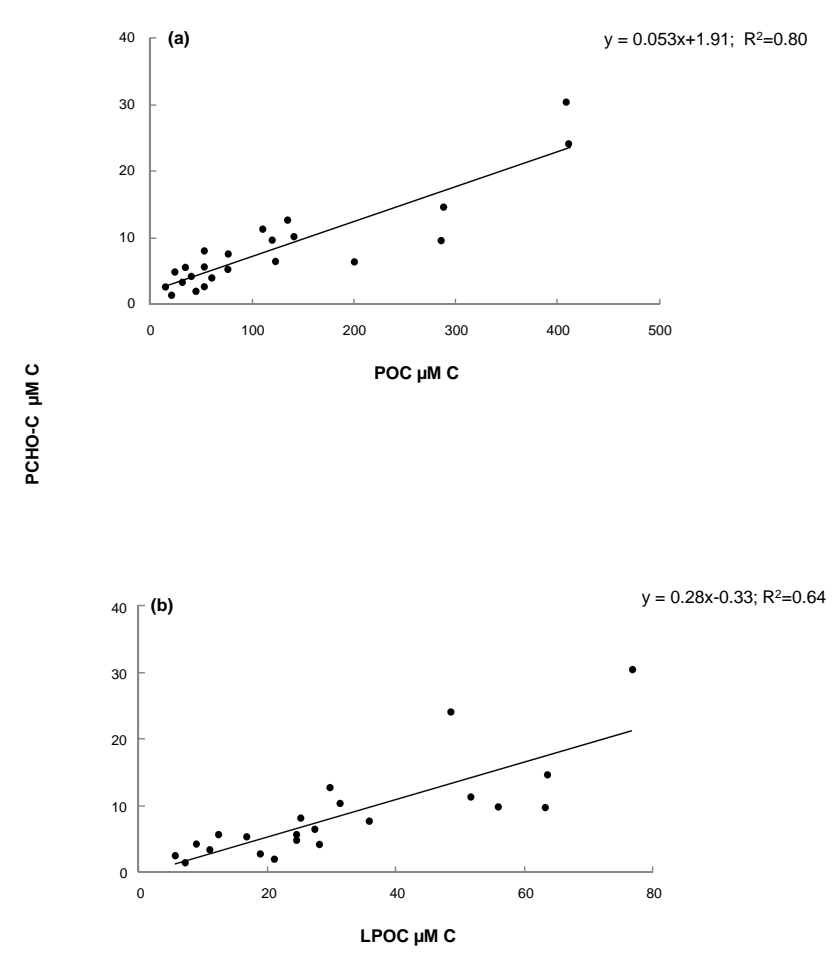

Fig. 2. Relationships between PCHO-C and (a) POC; (b) LPOC during the sampling period (May 2007-June 2009). Labile POC was calculated as follows: $0-15 \mathrm{mg}^{-1} \mathrm{TSM}$ corresponds to $35.2 \%$ LPOC; $15-50 \mathrm{mg} \mathrm{l}^{-1} \mathrm{TSM}, 46.60 \%$ LPOC; 50-150 $\mathrm{mg} \mathrm{l}^{-1} \mathrm{TSM}$, LPOC $22.10 \%$; $150-500 \mathrm{mg}^{-1} \mathrm{TSM}, 11.8 \%$ LPOC; 500-1500 $\mathrm{mg}^{-1}$ TSM, $18.8 \%$ LPOC (Ittekkot, 1988).

do not exist. Nevertheless, if we assume that carbohydrates constitute the major fraction of the LDOC (DCHO-C/DOC $=7 \%$; Table 3), the average flux of LDOC would average $0.044 \times 10^{10}$ moles $\mathrm{C} \mathrm{yr}^{-1}$, which is in agreement with the annual flux of DCHO $\left(0.042 \times 10^{10}\right.$ moles $\mathrm{yr}^{-1}$; Table 4). The remaining refractory-DOC (RDOC) can be calculated as the difference between DOC and LDOC and equals $0.59 \times 10^{10}$ moles $\mathrm{yr}^{-1}$. 
Our LDOC fluxes are approximately four times lower than that of $0.16 \times 10^{10}$ moles $C \mathrm{yr}^{-1}$ reported by Sempéré et al. (2000); however, it is important to note that the latter authors estimated LDOC fluxes using literature data by applying a mean of LDOC/DOC $=15 \%$ (Spitzy and Ittekkot, 1991; Volk et al., 1997). Our LDOC fluxes are likely underestimated because no amino acids were measured in this study. Unfortunately, no amino acid data are available for the Rhône River; nevertheless, previous investigations have suggested that amino acids generally account for $1-3 \%$ of DOC in rivers (Lara et al., 1998; Amon and Meon, 2004; Duan and Bianchi, 2007). Applying a LDOC/DOC ratio of $10 \%$ (DCHO-C/DOC + DAA-C/DOC), the LDOC flux in the Rhône River would average $0.063 \times 10^{10}$ moles $\mathrm{C} \mathrm{yr}^{-1}$, which is good agreement with the average value reported by Sempéré et al. (2000).

\subsection{Seasonal and interannual variability of bulk carbohydrates}

The high PCHO-C/POC values $(>9 \%)$ observed in the spring of 2008 (11, 25 March; April 2008) and 2009 (3, 10 March; 7 April) along with the low TSM concentrations (6-27 $\mathrm{mg}^{-1}$ ) suggest a predominantly autochthonous input of POM such as in situ primary production (Fig. 3). This is in agreement with previous investigations in which LPOC is generally associated with low TSM concentrations (Meybeck, 1982; Ittekkot and Arain, 1986; Ittekkot, 1988; Sempéré et al., 2000). Although chlorophyll data were not available during the sampling period, previous chlorophyll measurements over a period of $20 \mathrm{yr}$ (1980-1999) showed that fresh organic matter is regularly produced in spring and summer. In agreement with these observations, Harmelin et al. (2010) reported that the low $\mathrm{C} / \mathrm{N}$ ratios $(\mathrm{C} / \mathrm{N}<8)$ associated with the high organic carbon content $(\% \mathrm{C} \sim 4 \%)$ in $\mathrm{POM}$ are mainly observed in the spring and summer, coinciding with higher growth of diatoms and chlorophytes. In contrast, in the fall and winter, the $\mathrm{C} / \mathrm{N}$ ratios were higher $(>8)$ and were associated with low $\% \mathrm{C}(\sim 2 \%)$, suggesting the predominance of allochthonous terrestrial material in $\mathrm{POM}$ (Harmelin et al., 2010).

The lowest OC \% content and $\mathrm{PCHO}-\mathrm{C} / \mathrm{POC}$ ratios were observed during flood episodes and were associated with higher TSM concentrations (Tables 1, 2; Fig. 3), which further indicates that POM is mainly derived from allochthonous material originating from soils or litter in the drainage area. The carbohydrates in this allochthonous POM are probably associated with humic substances (Koivula and Hänninen, 2001; Fischer et al., 2007) or derived from highly degraded cellulosic material (Moran and Hodson, 1989). Although high phytoplanktonic production occurs in the spring, the flood events observed in this period generally diminish the production of autochthonous material because of the reduced light penetration to the river (Thurman, 1985).

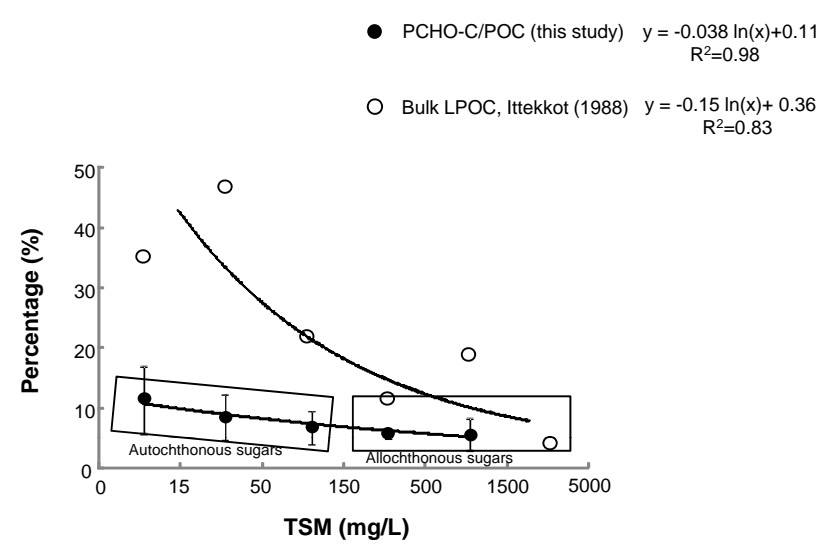

Fig. 3. The percentage of labile POC as a function of the TSM concentrations. In our study, the Rhône River TSM concentrations ranged between 6 and $1044 \mathrm{mg}^{-1}$; therefore, TSM > $1500 \mathrm{mg} \mathrm{l}^{-1}$ are not available. The error bars represent the standard deviation of the TSM concentrations for the range of 0-15, 15-50, 50-150, 150-500, and 500-1500 $\mathrm{mg}^{-1}$, as established by Meybeck (1982).

The PCA was further used to assess the differences in the carbohydrate content of the particulate samples. Two principal components were identified that accounted for almost $98 \%$ of the total variance in POM (Fig. 4a). Our results showed that, during flood events, carbohydrates exhibited a distinct molecular composition, which is typical of each flood event and clearly differs from that of low-water periods. Figure 4a also indicates that, in low-water periods, carbohydrates exhibit compositional similarities to POM (the points cluster in the middle of the figure), which probably suggests a common source.

Earlier investigations in the Rhône River suggested that phytoplankton contributes only $10 \%$ to the annual POC, whereas soil organic matter, an allochthonous material, is the major source of POC (Harmelin et al., 2010). Therefore, it appears that POM at the sampling site has an allochthonous signature, which makes imperceptible the organic matter produced within the river (autochthonous source). In agreement with these findings, other studies based on the $\delta^{13} \mathrm{C}$ measurements of fatty acids indicated that POM consists of a mixture of different sources with a strong contribution from terrestrial plants (allochthonous source) and a smaller input from freshwater microalgae, mostly diatoms (Bourgeois et al., 2011).

In contrast to $\mathrm{PCHO}$, the DCHO concentrations did not exhibit large variations between flood and low-water events, which further indicates that flood episodes mainly affect the PCHO pool rather than DCHO pool (Fig. 1b; Table 3). In accordance with that, our PCA results showed that the DCHO concentrations during flood events were generally similar to the DCHO concentrations measured during low-water events (Fig. 4c). The PCA also showed that the DCHO concentrations could explain only $55 \%(\mathrm{PC} 1+\mathrm{PC} 2)$ of the variability 

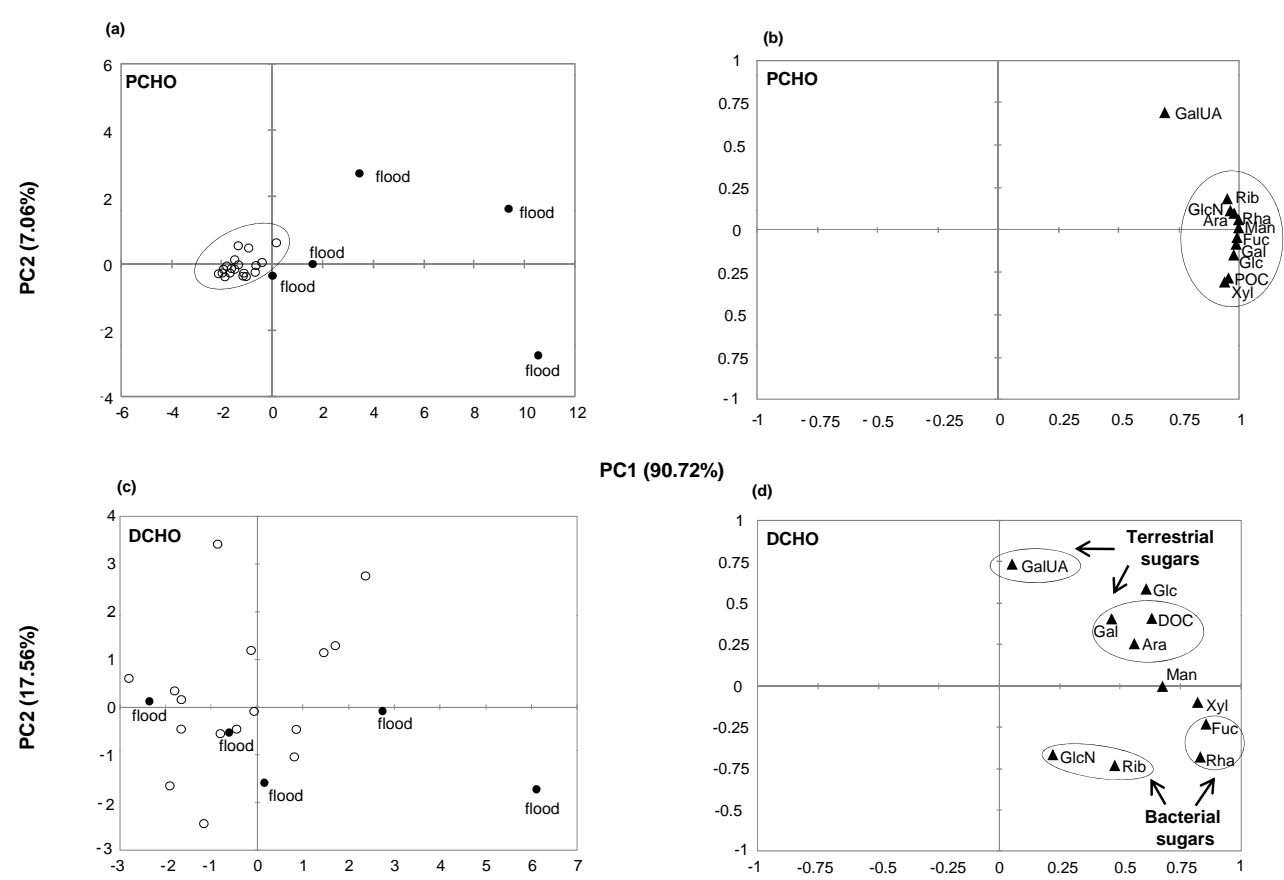

PC1 $(90.72 \%)$

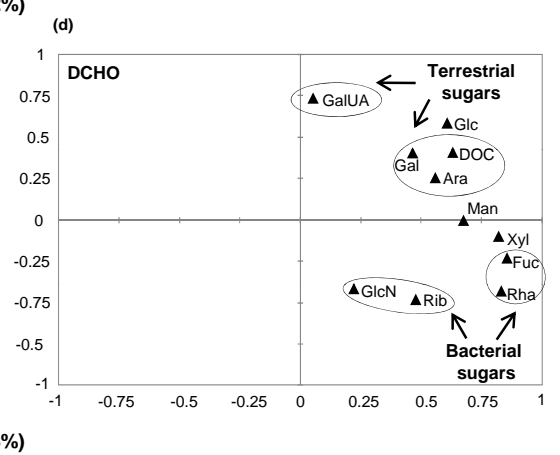

Fig. 4. Principal components analysis for particulate and dissolved carbohydrates, including POC and DOC. (a) and (c) are the sample scores, whereas (b) and (d) are the sample loadings of the PCA. The variance accounted for by each principal component is shown in parentheses after the axis label. The abbreviations of the sugars are given in Table 2.

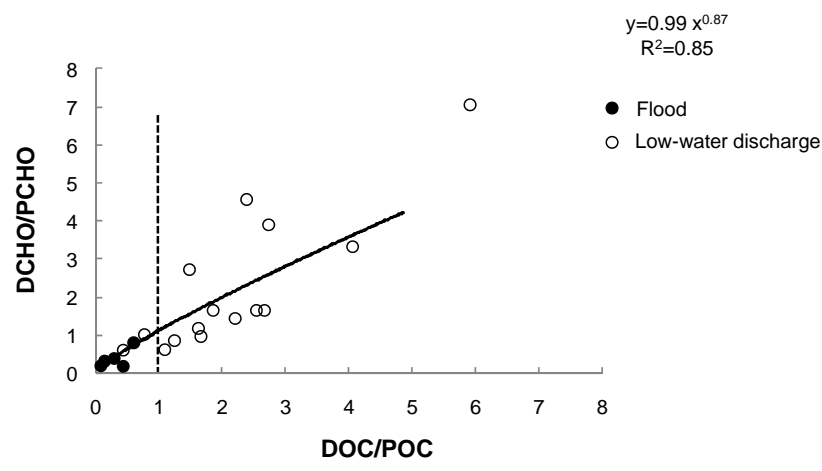

Fig. 5. Relationship between the ratios $\mathrm{DCHO} / \mathrm{PCHO}$ and DOC/POC during the sampling period. We considered a flood event to occur when $Q>3000 \mathrm{~m}^{3} \mathrm{~s}^{-1}$. This value roughly corresponded with two times the average annual flow recorded in the Rhône River $\left(Q=\sim 1500 \mathrm{~m}^{3} \mathrm{~s}^{-1}\right)$.

in the DOM pool, which probably indicates different DCHO sources (Fig. 4c; see later discussion).

Over the two-year period of study, DCHO dominated over PCHO throughout low water events $(\mathrm{DCHO} / \mathrm{PCHO}>1)$, indicating a higher DCHO transport during the low discharge periods (Table 1). A significant relationship between DOC/POC and DCHO/PCHO was established in this study (Fig. 5), further suggesting that the carbohydrate pool
$(\mathrm{PCHO}+\mathrm{DCHO})$ covaries with the bulk of organic matter $(\mathrm{TOC}=\mathrm{POC}+\mathrm{DOC})$, although total carbohydrates make up on average a small percentage of TOC $(15 \%$; Tables 2 and 3).

\subsection{Carbohydrate compositional patterns}

The patterns of occurrence of the individual carbohydrates over the period studied indicated that glucose was the dominant sugar in PCHO and DCHO ( $33 \%$ in average; Tables 3 , 4). Glucose was also found to be the dominant carbohydrate in the Parana (PCHO 30-45\%; DCHO 35-45\%; Depetris and Kempe, 1993), Caroni (DCHO 50\%; Ittekkot et al., 1982), Niger (DCHO $45 \%$; Ittekkot et al., 1982), Orinoco (DCHO 28\%; Ittekkot et al., 1982), Amazon (PCHO 35$50 \%$, DCHO $25 \%$; Hedges et al., 1994), and São Franscisco rivers (PCHO 35-60 \%; Jennerjahn and Ittekkot, 1999). With a few exceptions, glucose generally accounted for $>35 \%$ of the DCHO during flood events compared to the low-water discharge periods (Table 3). This enrichment of glucose in the DCHO pool is probably due to the weathering of soils or the transport of carbohydrate polymers (e.g. cellulose) from vascular plants (Cowie and Hedges, 1984; Fischer et al., 2007).

Galactose was the second most abundant carbohydrate in PCHO, whereas mannose and galactose contributed approximately equally $(\sim 11 \%)$ to the DCHO pool (Tables 3 and 4 ). 
In a terrestrial environment, galactose may derive from various sources, such as non-woody plant tissues, phytoplanktonic cell walls and bacteria in soils (Hecky et al., 1973; Cowie and Hedges, 1984; da Cuhna et al., 2002). The higher abundances of galactose in the PCHO pool (av. 16\%) than in the DCHO pool (av. 11\%) most likely suggest a phytoplanktonic influence in POM (see also the previous discussion). Other studies have found an enrichment of galactose in the particulate material in a coastal environment and/or sediments where primary productivity is generally high (Cowie and Hedges, 1984; Bergamaschi et al., 1999; He et al., 2010).

Although mannose was not among the most abundant carbohydrates in the $\mathrm{PCHO}$ pool, its contribution to the $\mathrm{PCHO}$ reached maximum values during flood events (except 22 April 2008; Table 2). Figure 6a shows a significant correlation between mannose in POM and discharge. This relationship indicates an enrichment in mannose of the particulate carbohydrate pool during high discharge periods, which probably reflects a local temporal influence by angiosperms (i.e. flowering plants). The reported percentages of mannose for angiosperms (leaves or grasses) fall into the range of 8-20\% and are similar to our results (Cowie and Hedges, 1984).

Fucose and rhamnose contributed approximately equally to both the PCHO and DCHO pools (6-7\%; Tables 2 and $3)$. These two carbohydrates were strongly associated in both POM and DOM, as shown by the strong correlations coefficients (POM: Fuc $=1.62 \times$ Rha $-0.14, r=0.98, n=25$, $p<0.0001$ and DOM: Fuc $=1.19 \times$ Rha $-0.08, r=0.94$, $n=21, p<0.0001)$. Although fucose and rhamnose may have various sources, such as vascular plants, planktons and bacteria, their strong association and their high abundance in POM and DOM pools (av. 18-21\%, calculated on a glucose-free basis) clearly suggest a bacterial contribution (Cowie and Hedges, 1984; Bergamaschi et al., 1999) (Fig. 4d). Moreover, the high abundances of deoxysugars strongly point toward an advanced decomposition status of the organic material (see later discussion). Amino sugars and ribose are not the major structural components of vascular plants; they generally are components of the microbial biomass in plant detritus, particularly in more highly degraded material (Hicks et al., 1994). Glucosamine and ribose formed a cluster close to fucose and rhamnose, which further reinforces the idea that these carbohydrates probably have a common bacterial origin and are typical of highly degraded organic material in POM and DOM (Fig. 4d).

In contrast to DOM, all carbohydrates in POM formed a compact cluster (except galacturonic acid, Fig. 4b). This result may suggest a common origin or a mixture of different origins; nevertheless, as indicated above, the allochthonous signature appears to dominate.
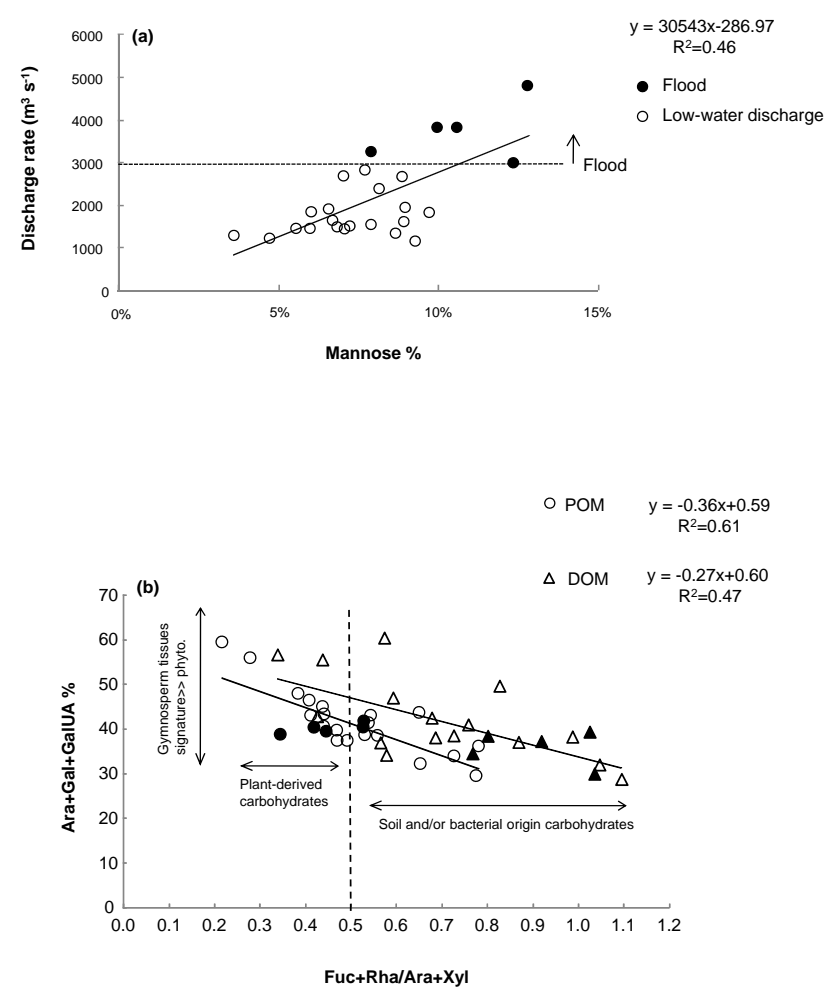

Fig. 6. (a) Relationships between mannose and discharge in POM and (b) relationships between the ratio Fuc $+\mathrm{Rha} / \mathrm{Ara}+\mathrm{Xyl}$ and $\mathrm{Ara}+\mathrm{Gal}+\mathrm{GalUa}(\%)$ in POM and DOM over the sampling period. Flood events are indicated as bold circles and triangles.

\subsection{Carbohydrate origins in the Rhône River}

The origins of carbohydrates in both the POM and DOM pools were further assessed using the carbohydrate compositional patterns, similarly to previous investigations (Cowie and Hedges, 1984; da Cunha et al., 2002; Guggenberger et al., 1994; He et al., 2010). Because glucose composition may vary with sources, the following calculations were performed on a glucose-free basis.

Figure $6 \mathrm{~b}$ displays a plot between $(\mathrm{Fuc}+\mathrm{Rha}) /(\mathrm{Ara}+\mathrm{Xyl})$ and Ara + Gal + GalUA \% for both POM and DOM. The $($ Fuc + Rha $) /($ Ara + Xyl) ratio has been used as an indicator of soil and/or bacterial-derived organic matter (when $>0.5)$ and of plant derived carbohydrates (when $<0.5$ ) (Guggenberger et al., 1994). Our results showed that most of the DOM carbohydrate data, including the flood episodes, exhibit values higher than 0.5 , which further suggests a soil or bacterial origin. In contrast, more than half of the POM carbohydrate data exhibited values $<0.5$, pointing to a vascular plant origin.

Wood may be differentiated from non-woody vascular plant tissues (e.g. leaves, grasses), because the latter contain higher amounts of pectin (a carbohydrate polymer containing mainly galacturonic acid and smaller amounts of 
arabinose and galactose). Cowie and Hedges (1984) used the formula $(\mathrm{Ara}+\mathrm{Gal}) \%$ as an indicator of non-woody vascular tissues and grasses (when 20-50\%) or woody origin $(<15 \%)$. Because our study measured galacturonic acid, we also included this compound in the above calculation (i.e. Ara $+\mathrm{Gal}+\mathrm{GalUA} \%$ ). Our results showed that the sum of these carbohydrates ranged from $28-60 \%$, which further suggests that POM and DOM in the sampling site have a non-woody vascular plant signature (e.g. angiosperms leaves/grasses, gymnosperms tissues). This result corroborates the PCA, where Ara, Gal, and DOC formed a compact cluster in the upper right quadrant (Fig. 4d). The above results clearly indicate that DOM at the sampling site exhibits vascular plant, soil, and bacterial signatures, whereas POM has a more pronounced terrestrial influence from vascular plants, with a small a contribution of in situ phytoplanktonic production (see above).

The fact that galacturonic acid did not fall into the cluster of arabinose, galactose and DOC may indicate various sources for this compound. Galacturonic acid can derive from vascular plants, bacteria, or phytoplankton and is an important constituent of mucopolysaccharides and soil organic matter (Kenne and Lindberg, 1983; Bergamaschi et al., 1999; Fischer et al., 2007). Our results showed that galacturonic acid accounted for 3-12\% (Table 2) of our DOM samples. These values are higher than those reported for plankton $(0.7-0.9 \%)$ or sediment trap material $(0.4-1.8 \%$; Bergamaschi et al., 1999), but similar to that found in wood, leaves, needles (4-18\%; Bergamaschi et al., 1999) and soils (17\%; Fischer et al., 2007). These results reinforce the previous conclusions that the molecular abundance of galacturonic acid in riverine DOM most likely reflects the weathering of soils and/or vascular plant signatures.

The different vascular plant sources (angiosperms leaves/grasses vs. gymnosperms tissues) in POM and DOM were further assessed using $\mathrm{Xyl} \%$ and Man/Xyl ratios. Our results showed that xylose accounted for $15-27 \%$ and $8-16 \%$ of the PCHO and DCHO, respectively. Xylose is produced in higher amounts by angiosperms than gymnosperms, whereas gymnosperms produce more mannose than xylose (Cowie and Hedges, 1984). Therefore, the higher abundances of xylose in PCHO probably suggest an angiosperm source (i.e. angiosperm leaves or grasses), whereas the lower abundances in DCHO suggest a gymnosperm source (i.e. non-woody gymnosperm tissues) (Cowie and Hedges, 1984; Bergamaschi et al., 1999; Jia et al., 2008). In agreement with this, the Man/Xyl ratios were $>1$ in DOM than in POM which is typical of gymnosperm source. Therefore, it appears that DOM at the sampling site exhibits an allochthonous influence of gymnosperms, which probably has its origin from the northern part of the Rhône (the Alps, Lake Geneva), where conifers dominate.

Alternatively, the low abundances of xylose in DOM may originate from selective degradation of the glucose and xylose in POM. Indeed, Opsahl and Benner (1999) showed a decrease in the xylose and glucose of different plant tissues, including leaves, wood, cypress needles and cord grass, over a four-year decomposition experiment. It is worth noticing that a similar relative abundance of xylose (11-16\%, recalculated on a glucose-free basis) was also reported in the surface sediments in the Gulf of Lions (the northwestern Mediterranean Sea) into which the Rhône River flows (Kerhervé et al., 2002).

\subsection{Carbohydrates as indicators of the diagenetic status of riverine DOM and POM}

The ubiquitous character of carbohydrates in terrestrial ecosystems allows not only the identification of their sources but also the evaluation of the biogeochemical processes (fates, metabolic pathways) occuring in the environment (Cowie and Hedges, 1984; Ittekkot and Arain, 1986; Hedges et al., 1994; Opsahl and Benner, 1999; Benner and Opsahl, 2001; He et al., 2010). For example, high hexoses/pentoses (Hex/Pen) ratios are indicative of labile organic matter originating mainly from plants, whereas low ratios indicate degraded material reflecting a soil origin (Ittekkot and Arain, 1986; da Cunha et al., 2002). Our results showed that the Hex/Pen ratios varied from 0.8 to 4.0 (av. 2.2) and from 1.4 to 6 (av. 2.9) for POM and DOM, respectively. Similar values have been reported for the Parana River (POM: 2.5-3.4; DOM: 6.3; Depetris and Kempe, 1993). These findings may imply that POM is more degraded than DOM in the sampling site. However, if we conduct the same calculation on a glucose-free basis $(\mathrm{Hex} / \mathrm{Pen}=\mathrm{Gal}+\mathrm{Man} / \mathrm{Ara}+\mathrm{Xyl})$ the Hex/Pen ratio will range from 0.5 to 1.3 (av. 0.9) for POM and 0.6 to 1.9 (av. 1.1) for DOM. This result further indicates that POM and DOM exhibit similar diagenetic alteration.

The observed differences are probably due to the apparent dominance of glucose among the carbohydrates in highly degraded material (e.g. soils, vascular plants; Opsahl and Benner, 1999; Fischer et al., 2007) and in fresh material as well (e.g. plankton; Cowie and Hedges, 1984; Biersmith and Benner, 1998). The reported mole percentages of glucose in highly degraded vascular plant tissues ranged from $30-50 \%$ (Opsahl and Benner, 1999) and are similar to those found in this study ( $\sim 33 \%$; Tables 2 and 3$)$ or other riverine systems (Ittekkot and Arain, 1986; Depetris and Kempe, 1993; Hedges et al., 1994). Although the processes that control the degradation of organic matter are not well known, growing evidence shows that the apparent degraded signature of riverine DOM can actually attributed to processes of leaching and sorption with respect to amino acids (Aufdenkampe et al., 2001) and lignin phenols (Hernes et al., 2007). However, very little is known regarding the behavior of carbohydrates.

Our results demonstrate that POM and DOM at the sampling site have already undergone extensive transformation, which is further supported by the relative abundances of deoxysugars. (Fuc + Rha) \% values calculated on a glucosefree basis ranged from 14 to $26 \%$ (av. 18\%) and from 14 
to $23 \%$ (av. $21 \%$ ) for POM and DOM, respectively. Our values are similar to those reported for ultrafiltrated DOM and fine $(<63 \mu \mathrm{m}) \mathrm{POM}$ in the Amazon river (Hedges et al., 1994) and agree as well with the deoxysugar values recorded at the end of decomposition experiments of vascular plants (Opsahl and Benner, 1999). Alternatively, the elevated deoxy sugar levels may arise from contributions from external sources (see above), such as microbial biomass (Cowie and Hedges, 1984; Panagiotopoulos and Sempéré, 2007). Regardless of the exact mechanism, our results clearly suggest that POM and DOM at the Arles station had undergone considerable degradation within the river and/or before entering the river.

\subsection{Export of terrestrial organic carbon of the Rhône River into the Gulf of Lions}

Rivers discharge POC at a rate that is similar to the global accumulation rate of organic carbon in all marine sediments (Berner, 1989). Previous studies indicated that the annual deposition of POC in the proximal Rhône prodelta and the distal Rhône prodelta were $8.0 \pm 5.0 \times 10^{10} \mathrm{~g} \mathrm{yr}^{-1}$ and $2.9 \pm 1.2 \times 10^{10} \mathrm{~g} \mathrm{yr}^{-1}$, respectively (De Madron et al., 2000). If we assume that only RPOC accumulates on the adjacent shelf or slopes (although a portion of RPOC may undergo extensive alteration through photochemistry or other biotic processes when exiting the river), our results suggest that the RPOC annual fluxes were on average $9 \times 10^{10} \mathrm{~g} \mathrm{C} \mathrm{yr}^{-1}$ and are in agreement with previous observations.

Considering a surface area of $23000 \mathrm{~km}^{2}$ and assuming that DOC comprises most of the TOC, with concentrations of approximately $70 \mu \mathrm{M} \mathrm{C}$ in surface $(0-200 \mathrm{~m})$ and $40 \mu \mathrm{M}$ below $500 \mathrm{~m}$ (Santinelli et al., 2010 and references therein), the standing stock of TOC in the Gulf of Lions is $\sim 145 \times 10^{10}$ moles $\mathrm{C}$. The annual TOC (POC + DOC) input from the Rhône is $1.7 \times 10^{10}$ moles $\mathrm{C}$ (Table 4) and represents only $\sim 1 \%$ of the standing stock of TOC in the Gulf of Lions. Expanding our results to the entire Mediterranean Sea, the annual TOC input of the Rhône River accounts for $\sim 0.007 \%$ of the Mediterranean standing stock of TOC and is in agreement with previous estimations $(\sim 0.01 \%$; Sempéré et al., 2000).

Our results also showed that carbohydrates accounted for $\sim 7 \%$ of TOC, whereas glucose represented $\sim 33 \%$ of the total carbohydrates (Tables 2 and 3). This corresponds to annual flux of $3.8 \times 10^{8}$ moles glucose (or $6.9 \times 10^{10} \mathrm{~g}$ glucose) and it is in the same order of magnitude with the inputs of other species such as total nitrogen (11.5$\left.12.7 \times 10^{10} \mathrm{~g} \mathrm{yr}^{-1}\right)$, phosphorus $\left(0.65-1.2 \times 10^{10} \mathrm{~g} \mathrm{yr}^{-1}\right)$, and silicate (13.5-13.9 $\times 10^{10} \mathrm{~g} \mathrm{yr}^{-1}$ ) (Moutin et al., 1998). The above results highlight the important contribution of the Rhône River to the Gulf of Lions and in Mediterranean Sea in general.

\section{Conclusions}

The conclusions of this seasonal investigation of the carbohydrate species and related chemical parameters (POC and DOC) and their fluxes estimated for the Rhône River are summarized below:

a. Carbohydrates contributed approximately equally (av. $7-8 \%$ ) to both POM and DOM. PCHO followed the variations of $\mathrm{POM}$ and peaked during flood events, whereas DCHO and DOC did not show any specific trend between low and high discharge periods. Moreover, DOC and consequently DCHO concentrations were not correlated with the water discharge, suggesting a decoupling between particulate and dissolved organic matter.

b. The information on the concentration and composition of carbohydrates provided important indications of organic matter sources and the degree of diagenesis. Our results showed that, during flood events, PCHO exhibited a distinct molecular composition (Fig. 4a), rich in mannose, which is typical of each flood event. This enrichment in mannose probably reflects an allochthonous origin, most likely from angiosperms (leaves or grasses). In lowwater periods, PCHO exhibited compositional similarities to POM, indicating a terrestrial origin (again an allochthonous source), which conceals the organic matter produced within the river (autochthonous source). Based on the (Fuc + Rha)/(Ara + Xyl), Man/Xyl ratios, $\mathrm{Xyl} \%$ and (Ara+Gal+GalUA) \%, with the relative abundances calculated on a glucose-free basis, our results showed that DCHO had different terrestrial origins (gymnosperms tissues and soils), including bacteria (Fig. 4d; Fig. 6b). Galactose and arabinose cluster together with DOC in the PCA, indicating that the origins of these sugars are probably reflected in DOC. The Hex/Pen ratios and (Fuc + Rha) \% relative abundances, both calculated on a glucose-free basis, indicated that POM and DOM had undergone considerable degradation within the river and/or before entering the river.

c. Galacturonic acid abundances in riverine organic matter showed that this compound has a good potential for tracking terrestrial organic matter origins. Similar compounds (methylated uronic acids) were also detected, but they were not identified within the uronic acid pool. As such, additional information was lost about the origins of these carbohydrates; therefore, further studies are needed to better understand their roles and distributions in the terrestrial and marine environments.

d. The estimated carbohydrate fluxes from the Rhone River into the Mediterranean Sea over the sampling period averaged $0.064 \pm 0.026 \times 10^{10}$ moles $\mathrm{yr}^{-1}$ 
of PCHO and $0.042 \pm 0.008 \times 10^{10}$ moles $\mathrm{Cyr}^{-1}$ of DCHO, representing $6 \%$ and $7 \%$ of the annual flux of POC and DOC, respectively. These results are in accordance with previous flux estimates for bulk POC and DOC over the period 1987 and 1996 (Sempéré et al., 2000). Finally, by expanding our results to the Gulf of Lions (the northwestern Mediterranean Sea), we found that TOC fluxes accounted for $\sim 1 \%$ of the standing stock of seawater TOC. Glucose is the most abundant carbohydrate in both the particulate and dissolved organic matter pools, and its annual flux into the Gulf of Lion was estimated to be $3.8 \times 10^{8}$ moles glucose.

Acknowledgements. This research was funded by the French National Research Agency, program "Vulnérabilités: Milieux et Climat" under the grant CHACCRA (contract number ANRVULN-06-001-01), the French INSU-EC2CO program RiOMar.fr, and the MANDARINE project (region Provence Alpes Côte d'Azur). The manuscript benefited from advice and comments rom W. Ludwig, M. Tedetti and the three anonymous reviewers. Liquid discharges values in Arles were made available thanks to the CNR. The authors gratefully acknowledge M. Fornier and M. Thaust for analytical and field assistance.

Edited by: K. Suzuki

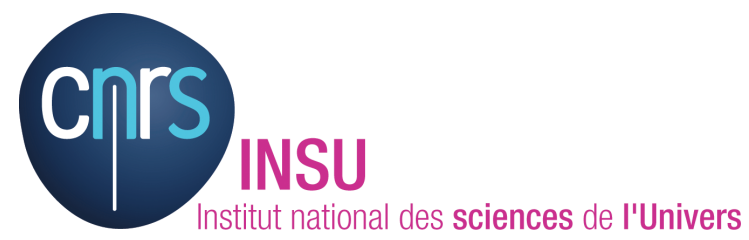

The publication of this article is financed by CNRS-INSU.

\section{References}

Alin, S. R., Aalto, R., Goni, M. A., Richey, J. R., and Dietrich, W. E.: Biogeochemical characterization of carbon sources in the Strickland and Fly rivers, Papua New Guinea, J. Geophys. Res.Earth., 113, F01S05, doi:10.1029/2006JF000625, 2008.

Amon, R. M. W. and Benner, R. Combined neutral sugar as indicators of the diagenetic state of dissolved organic matter in the Arctic Ocean, Deep-Sea Res. Part I, 50, 151-169, 2003.

Amon, R. M. W. and Meon, B.: The biogeochemistry of dissolved organic matter and nutrients in two large Arctic estuaries and potential implications for our understanding of the Arctic Ocean system, Mar. Chem., 92, 311-330, 2004.

Aufdenkampe, A. K., Hedges, J. I., Richey, J. E., Krusche, A. V., and Llerena, C. A.: Sorptive fractionation of dissolved organic nitrogen and amino acids onto fine sediments within the Amazon Basin, Limnol. Oceanogr., 46, 1921-1935, 2001.

Aufdenkampe, A. K., Mayorga, E., Hedges, J. I., Llerena, C., Quay, P. D., Gudeman, J., Krusche, A. V., and Richey, J. E.: Organic matter in the Peruvian headwaters of the Amazon: Composi- tional evolution from the Andes to the lowland Amazon mainstem, Org. Geochem., 38, 337-364, 2007.

Aufdenkampe, A. K., Mayorga, E., Raymond, P. A., Melack, J. M., Doney, S. C., Alin, S. R., Aalto, R. E., and Yoo, K.: Riverine coupling of biogeochemical cycles between land, oceans, and atmosphere, Front. Ecol. and Environ., 9, 53-60, 2011.

Benner, R.: What happens to the terrestrial organic matter in the Ocean, Mar. Chem., 92, 307-310, 2004.

Benner, R. and Opsahl, S.: Molecular indicators of the sources and transformations of dissolved organic matter in the Mississippi river plume, Org. Geochem., 32, 597-611, 2001.

Bergamaschi, B. A., Walters, J. S., and Hedges, J. I.: Distributions of uronic acids and O-methyl sugars in sinking and sedimentary particles in two coastal marine environments, Geochim. Cosmochim. Acta., 63, 413-425, 1999.

Bergfeld, T., Scherwass, A., Ackermann, B., Arndt, H., and Schol, A.: Comparison of the components of the planktonic food web in three large rivers (Rhine, Moselle, and Saar), River Res. and applications., 25, 1232-1250, 2009.

Berner, R. A.: Biogeochemical cycles of carbon and sulfur and their effect on the atmospheric oxygen over Phanerozoic time, Palaeogeogr. Palaeoclim. Palaeoecol., 75, 97-122, 1989.

Bethoux, J. P. and Gentili, B.: Functioning of the Mediterranean Sea: past and present changes related to freshwater input and climate changes, J. Marine Syst., 20, 33-47, 1999.

Biersmith, A. and Benner, R.: Carbohydrates in phytoplankton and freshly produced dissolved organic matter, Mar. Chem., 63, 131144, 1998.

Bourgeois, S., Pruski, A. M., Sun, M.-Y., Buscail, R., Lantoine, F., Kerhervé, P., Vétion, G., Rivière, B., and Charles, F.: Distribution and lability of land-derived organic matter in the surface sediments of the Rhône prodelta and the adjacent shelf (Mediterranean Sea, France): a multi proxy study, Biogeosciences, 8, 3107-3125, doi:10.5194/bg-8-3107-2011, 2011.

Bray, N. A., Ochoa, J., and Kinder, T. H.: The role of interface in exchange through the Strait of Gibraltar, J. Geophys. Res., 100, 755-776, 1995.

Cauwet, G., Gadel, F., de Souza Sierra, M. M., Donard, O., and Ewald, M.: Contribution of the Rhône River to organic carbon input to the northwestern Mediterranean Sea, Cont. Shelf Res., 10, 1025-1037, 1990.

Copin-Montégut, C.: Alkalinity and carbon budgets in the Mediterranean, Global Biogeochem. Cy., 7, 915-925, 1993.

Coste, C. and Raimbault, P.: Recent data on the nutrient inputs into the Mediterranean Sea by the Rhône River, in: EROS 2000, edited by: Martin, J. M. and Barth, H., NERC, Plymouth, UK Water Pollut. Res. Rep., 30, 47-50, 1993.

Cowie, G. L. and Hedges, J. I.: Carbohydrate sources in a coastal marine environment, Geochim. Cosmochim. Acta., 48, 20752087, 1984.

da Cunha, L. C., Serve, L., and Blazi, J. L.: Neutral sugars as biomarkers in the particulate organic matter of a French Mediterranean river, Org. Geochem., 33, 953-964, 2002.

Dagg, M., Benner, R., Lohrenz, S., and Lawrence, D.: Transformation of dissolved and particulate materials on continental shelves influenced by large rivers: plume processes, Cont. Shelf Res., 24, 833-858, 2004.

Degens, E. T., Kempe, S., and Richey, J. E.: Biogeochemistry of major world rivers, Scope 42, J.Wiley and Sons, Ltd, Chichester, 
1991.

De Leeuw, J. W. and Largeau, C.: A review of macromolecular organic compounds that comprise living organisms and their role in kerogen, coal, and petroleum formation, in: Organic Geochemistry, edited by: Engel, M. H. and Macko, S. A., Organic Geochemistry. Plenum, New York, 23-72, 1993.

De Madron, X., Abassi, A., Heussner, S., Monaco, A., Aloisi, J.C., Radakovitch, O., Giresse, P., Buscail, R., and Kerhervé, P. Particulate matter and organic carbon budgets for the Gulf of Lions (NW Mediterranean), Oceanol. Acta, 23, 717-729, 2000.

De Madron, X., Denis, L., Diaz, F., Garcia, N., Guieu, C., Grenz, C., Loye-Pilot, M. D., Ludwig, W., Moutin, T., Raimbault, P., and Ridame, C.: Nutrients and carbon budgets for the Gulf of Lion during the Moogli cruises, Oceanol. Acta, 26, 421-433, 2003.

Depetris, P. J. and Kempe, S.: Carbon dynamics in the Parana River, Limnol. Oceanogr., 38, 382-395, 1993.

Duan, S. and Bianchi, T. S.: Particulate and dissolved amino acids in the lower Mississippi and Pearl Rivers (USA), Mar. Chem., 107, 214-229, 2007.

Eyrolle, F., Radakovitch, O., Raimbault, P., Antonelli, C., Ferrand, E., Jacquet, S., Aubert, D., Raccasi G., and Gurriaran, R: Long term survey of suspended particles and associated natural and artificial radionuclides transport in the Rhône River (South eastern France), applied Geochemistry, accepted, 2012.

Fischer, H., Meyer, A., Fischer, K., and Kuzyakov, Y.: Carbohydrate and amino acid composition of dissolved organic matter leached from soil, Soil Biol. Biochem, 39, 2926-2935, 2007.

Guggenberger, G., Christensen, B. T., and Zech, W.: Land use effects on the composition of organic matter in particlesize separates of soil: I. Lignin and carbohydrate signature, Eur. J. Soil Sci., 45, 449-458, 1994.

Harmelin, M., Dierking, J., Banaru, D., Fontaine, M. F., and Arlhac, D.: Seasonal variation in stable $\mathrm{C}$ and $\mathrm{N}$ isotope ratios of the Rhône River inputs to the Mediterranean Sea (2004-2005), Biogeochemistry, 100, 139-150, 2010.

Hecky, R. E., Mopper, K., Kilham, P., and Degens, E. T.: The amino acid and sugar composition of diatom cell walls, Mar Biol., 19, 323-331, 1973.

Hedges, J. I., Cowie, G. L., Richey, J. E., Quay, P. D., Benner, R., Strom, M., and Forsberg, B. R.: Origins and processing of organic matter in the Amazon River as indicated by carbohydrates and amino acids, Limnol. Oceanogr., 39, 743-761, 1994.

Hedges, J. I., Keil, R. G., and Benner, R.: What happens to the terrestrial organic matter in the Ocean, Org. Geochem., 27, 195212, 1997.

Hernes, P. J., Robinson, A. C., and Aufdenkampe, A. K: Fractionation of lignin during leaching and sorption and implications for organic matter "freshness", Geophys. Res. Lett., 34, L17401, doi:10.1029/2007GL031017, 2007.

He, B., Dai, M., Huang, W., Liu, Q., Chen, H., and Xu, L.: Sources and accumulation of organic carbon in the Pearl River Estuary surface sediment as indicated by elemental, stable carbon isotopic, and carbohydrate compositions, Biogeosciences, 7, 33433362, doi:10.5194/bg-7-3343-2010, 2010.

Hicks, R. E., Owen, C. J., and Aas, P.: Deposition, resuspension, and decomposition of particulate organic matter in sediments of Lake Itascha, Minnesota, USA, Hydrobiogia, 284, 79-91, 1994.
Ibanez, C., Pont, D., and Prat, N.: Characterization of the Ebre and Rhône estuaries: a basis for defining and classifying saltwedge estuaries, Limnol. Oceanogr., 42, 89-101, 1997.

Ittekkot, V.: Global trends in the nature of organic matter in river suspensions, Nature, 332, 436-438, 1988.

Ittekkot, V. and Arain, R. Nature of particulate organic matter in the river Indus, Pakistan, Geochim. Cosmochim. Acta, 50, 16431653, 1986.

Ittekkot, V., Spitzy, A. N., and Lammerz, U.: Data on dissolved carbohydrates and amino acids in world rivers: A documentation, in: Transport of Carbon and Minerals in Major World Rivers, edited by: Degens, E. T., Pt. 1., 575-584, Mitt. GeoI. PalaontoI. Inst. Univ. Hamburg SCOPE/UNEP Sonderbd., 52, 1982.

Jennerjahn, T. C. and Ittekkot, V.: Changes in organic matter from surface waters to continental slope sediments off the São Francisco River, eastern Brazil, Mar. Geol., 161, 129-140, 1999.

Jia, G., Dungait, J. A. J., Bingham, E. M., Valiranta, M., Korhola, A., and Evershed, R. P.: Neutral monosaccharides as biomarkers proxies for bog-forming plants for application to paleovegetation reconstruction in ombrotrophic peat deposits, Org. Geochem., 39, 1790-1799, 2008.

Kao, S. J. and Liu, K. K.: Particulate organic carbon export from a subtropical mountainous river (Lanyang Hsi) in Taiwan, Limnol. Oceanogr., 41, 1749-1757, 1996.

Kao, S. J. and Liu, K. K.: Fluxes of dissolved and nonfossil particulate organic carbon from an oceania small river (Lanyang His) in Taiwan, Biogeochemistry, 39, 255-269, 1997.

Keil, R. G., Tsamakis, E., Giddings, J. C., and Hedges, J. I.: Biochemical distributions (amino acids, neutral sugars and lignin phenols) among size-classes of modern marine sediments from the Washington coast, Geochim. Cosmochim. Acta, 62, 13471364, 1988.

Keil, R. G., Mayer, L. M., Quay, P. D., Richey, J. E., and Hedges, J. I.: Loss of organic matter from riverine particles in deltas, Geochim. Cosmochim. Acta, 61, 1507-1511, 1997.

Kendall, C., Silva, S. R., and Kelly, V. J.: Carbon and Nitrogen isotopic compositions of particulate organic matter in four large river systems across the United States, Hydrol. Proces., 15, 1301-1346, 2001.

Kenne, L. and Lindberg, B.: Bacterial polysaccharides, in: The Polysaccharides, edited by: Aspinall, G. O., Academic Press, 287-365, 1983.

Kerhervé, P., Buscail, R., Gadel, F., and Serve, L.: Neutral monosaccharides in surface sediments of the northwestern Mediterranean Sea, Org. Geochem., 33, 421-435, 2002.

Koivula, N. and Hänninen, K.: Concentrations of monosaccharides in humic substances in the early stages of humification, Chemosphere, 44, 271-279, 2001.

Kujawinski, E. B., Freitas, M. A., Zang, X., Hatcher, P. G., GreenChurch, K. B., and Jones B. R.: The application of electrospray ionization mass spectrometry (ESI MS) to the structural characterization of natural organic matter, Org. Geochem., 33, 171180, 2002.

Lara, R. J., Rachold, V., Kattner, G., Hubberten, H. W., Guggenberger, G., Skoog, A., and Thomas, D. N.: Dissolved organic matter and nutrients in the Lena River, Siberian Arctic. Characteristics and distribution, Mar. Chem., 59, 301-309, 1998.

Mallin, M. A., Johnson, V. L., Ensign, S. H., and MacPherson, T. A.: Factors contributing to hypoxia in rivers, lakes, and streams, 
Limnol. Oceanogr., 51, 690-701, 2006.

Margat, J.: L'eau dans le basin méditerranéen, situation et prospective, in: Les fascicules du Plan Bleu, edited by: Margat, J., Economica Paris, 196 pp., 1992.

McKee, B. A., Aller, R. C., Allison, M. A., Bianchi, T. S., and Kineke, G. C.: Transport and transformation of dissolved and particulate materials on continental margins influenced by major rivers: benthic boundary layer and seabed processes, Cont. Shelf Res., 24, 899-926, 2004.

Meybeck, M.: Carbon, nitrogen, and phosphorus transport by world Rivers, Am. J. Sci., 282, 401-450, 1982.

Meybeck, M.: Riverine transport of atmospheric carbon: Sources, global typology and budget, Water Air Soil Pollut., 70, 443-463, 1983.

Mopper, K. and Kieber, D. J.: Photochemistry and the Cycling of Carbon, Sulfur, Nitrogen and Phosphorus, in: Biogeochemistry of Marine Dissolved Organic Matter, edited by: Hansell, D. and Carlson, C., Academic Press, 455-503, 2002.

Moran, M. A. and Hodsonj, R. E.: Formation and bacterial utilization of dissolved organic carbon derived from detrital lignocelluloses, Limnol. Oceanogr., 34, 1034-1047, 1989.

Moutin, T., Raimbault, P., Golterman, H. L., and Coste, B.: The input of nutrients by the Rhône river into the Mediterranean Sea: recent observations and comparison with earlier data, Hydrobiologia, 373/374, 237-246, 1998.

Ollivier, P., Hamelin, B., and Radakovitch, O.: Seasonal variations of physical and chemical erosion: A three-year survey of the Rhône River (France), Geochim. Cosmochim. Acta, 74, 907927, 2010.

Opsahl, S. and Benner, R.: Characterization of carbohydrates during early diagenesis of five vascular plant tissues, Org. Geochem., 30, 83-94, 1999.

Opsahl, S., Benner, R., and Amon, R. M. W.: Major flux of terrigenous dissolved organic matter through the Arctic Ocean, Limnol. Oceanogr., 44, 2017-2023, 1999.

Panagiotopoulos, C. and Sempéré, R.: Analytical methods for the determination of sugars in marine samples: A historical perspective and future directions, Limnol. Oceanogr. Meth., 3, 419-454, 2005a.

Panagiotopoulos, C. and Sempéré R.: The molecular distribution of combined aldoses in sinking particles in various oceanic conditions, Mar. Chem., 95, 31-49, 2005b.

Panagiotopoulos, C. and Sempéré, R.: Sugar dynamics in large particles during in vitro degradation experiments, Mar. Ecol. Prog. Ser., 330, 67-74, 2007.

Panagiotopoulos, C. and Wurl, O.: Spectrophotometric and chromatographic analysis of carbohydrates in marine samples, in: Practical Guidelines for Analysis of seawater, edited by: Wurl, O., Taylor and Francis, 2009.

Panagiotopoulos, C., Sempéré, R., Lafont, R., and Kerhervé, P.: Sub-ambient temperature effects on separation of monosaccharides by HPAEC-PAD. Application to marine chemistry, J. Chromatogr. A, 920, 13-22, 2001.

Para, J., Coble, P. G., Charrière, B., Tedetti, M., Fontana, C., and Sempéré, R.: Fluorescence and absorption properties of chromophoric dissolved organic matter (CDOM) in coastal surface waters of the northwestern Mediterranean Sea, influence of the Rhône River, Biogeosciences, 7, 4083-4103, doi:10.5194/bg-74083-2010, 2010.
Prahl, F. G., Ertel, J. R., Goni, M. A., Sparrow, M. A., and Eversmeyer, B.: An assessment of terrestrial organic carbon contributions to Washington coastal sediments, Geochim. Cosmochim. Acta, 58, 3035-3048, 1994.

Pont, D., Simonnet, J.-P., and Walter, A. V.: Medium-term changes in suspended sediment delivery to the ocean: consequences of catchment heterogeneity and river management (Rhône River, France), Estuar. Coast. Shelf Sci., 54, 1-18, 2002.

Rabouille, C., Conley, D. J., Dai, M. H., Cai, W.-J., Chen, C. T. A., Lansard, B., Green, R., Yin, K., Harrison, P. J., Dagg, M., and McKee, B.: Comparison of hypoxia among four river-dominated ocean margins: The Changjiang (Yangtze), Mississippi, Pearl, and Rhône Rivers, Cont. Shelf Res., 28, 1527-1537, 2008.

Raimbault, P., Garcia, N., and Cerutti, F.: Distribution of inorganic and organic nutrients in the South Pacific Ocean - evidence for long-term accumulation of organic matter in nitrogendepleted waters, Biogeosciences, 5, 281-298, doi:10.5194/bg-5281-2008, 2008.

Raymond, P. A. and Bauer, J. E.: Riverine export of aged terrestrial organic matter to the North Atlantic Ocean, Nature, 436, 538$541,2001$.

Reschke, S., Ittekkot, V., and Panin, N.: The nature of organic matter in the Danube river particles and north western Black Sea sediments, Estuar. Coast. Shelf Sci., 54, 563-574, 2002.

Santinelli, C., Nannicini, L., and Seritti, A.: DOC dynamics in the meso and bathypelagic layers of the Mediterranean Sea, DeepSea Res. Part II, 57, 1466-1459, 2010.

Schillawski, S. and Petsch, S.: Release of biodegradable dissolved organic matter from ancient sedimentary rock, Global Biogeochem. Cy., 22, GB3002, doi:10.1029/2007GB002980, 2008.

Sempéré, R., Charrière, B., Van Wambeke, F., and Cauwet, G.: Carbon inputs of the Rhone River to the Mediterranean Sea: Biogeochemical implications, Global Biogeochem. Cy., 14, 669-681, 2000.

Sicre, M. A., Fernandes, M. B., and Pont, D.: Poly-aromatic hydrocarbon (PAH) inputs from the Rhône river to the Mediterranean Sea in relation with the hydrological cycle: Impact of floods, Mar. Pollut. Bull., 56, 1935-1942, 2008.

Smith, S. V. and Hollibaugh, J. T.: Coastal Metabolism and the Oceanic organic carbon balance, Rev. Geophys., 31, 75-89, 1993.

Sohrin, R. and Sempéré, R.: Seasonal variation in total organic carbon in the northeast Atlantic in 2000-2001, J. Geophys. Res., 110, C10S90, doi:10.1029/2004JC002731, 2005.

Solomon, D., Lehmann, J., and Zech, W.: Land use effects on soil organic matter properties of chromic luvisols in semi-arid northern Tanzania: carbon, nitrogen, lignin and carbohydrates, Agr. Ecosyst. Environ., 78, 203-213, 2000.

Spencer, R. G. M., Hernes, P. J., Ruf, R., Baker, A., Dyda, R. Y., Stubbins, A., and Six, J.: Temporal controls on dissolved organic matter and lignin biogeochemistry in a pristine tropical river, Democratic Republic of Congo, J. Geophys. Res. Biogeosciences, 115, G03013, doi:10.1029/2009JG001180, 2010.

Spitzy, A. and Ittekkot, V.: Dissolved and particulate organic matter in rivers, in: Ocean Margin Processes in global change, edited by: Mantoura, R. F. C., Martin, J. M., and Wollast, R., Wiley Interscience, 5-17, 1991. 
Sweet, M. S. and Perdue, E. M.: Concentration and speciation of dissolved sugars in river water, Environ, Sci. Technol., 16, 692698, 1982.

Thurman, E. M.: Types and amount of dissolved organic carbon in natural waters, in: Organic Geochemistry of natural waters, edited by: Thurman, E. M., Kluwer academic publishers, 181213, 1985.

Vannote, R. L., Minshall, G. W., Cummins, K. W., Sedell, J. R., and Gushing, C. E.: The river continuum concept, Can. J. Fish. Aquat. Sci., 37, 130-137, 1980.
Vigier, N., Bourdon, B., Turner, S., and Allegre, C. J.: Erosion timescales derived from U-decay series measurements in rivers, Earth Planet. Sc. Lett., 193, 549-563, 2001.

Volk, C. J., Volk, C. B., and Kaplan, L. A.: Chemical composition of biodegradable dissolved organic matter in streamwater, Limnol. Oceanogr., 42, 39-44, 1997.

Wakeham, S. G., Lee, C., Hedges, J. I., Hernes, P. J., and Peterson, M. L.: Molecular indicators of diagenetic status in marine organic matter, Geochim. Cosmochim. Acta, 61, 5363-5369, 1997.

Yoro, S. C., Panagiotopoulos, C., and Sempéré, R.: Dissolved organic carbon contamination induced by filters and storage bottle, Water Res., 33, 1956-1959, 1999. 